\title{
Control Benefits and CEO Discipline in Automatic Bankruptcy Auctions
}

\section{B. Espen Eckbo}

Tuck School of Business

Karin S. Thorburn

University of Pennsylvania

Follow this and additional works at: https://repository.upenn.edu/fnce_papers

Part of the Finance Commons, and the Finance and Financial Management Commons

\section{Recommended Citation}

Eckbo, B. E., \& Thorburn, K. S. (2003). Control Benefits and CEO Discipline in Automatic Bankruptcy Auctions. Journal of Financial Economics, 69 (1), 227-258. http://dx.doi.org/10.1016/

S0304-405X(03)00126-0

Author Karin S. Thorburn is a full time faculty member of Norwegian School of Economics. She is a visiting professor in the Finance Department of the Wharton School at the University of Pennsylvania.

This paper is posted at ScholarlyCommons. https://repository.upenn.edu/fnce_papers/198

For more information, please contact repository@pobox.upenn.edu. 


\title{
Control Benefits and CEO Discipline in Automatic Bankruptcy Auctions
}

\author{
Abstract \\ Swedish bankruptcy filing automatically terminates the employment of the chief executive officer (CEO) \\ and triggers an auction of the firm. Critics of this system warn of excessive shareholder risk-shifting \\ incentives prior to filing. We argue that private benefits of control induce managerial conservatism that \\ may override shareholder risk-shifting incentives. By investing conservatively, the CEO increases the joint \\ probability that the auction results in a going-concern sale and that the CEO is rehired. This uniquely \\ implies that the rehiring probability is increasing in private control benefits, which our empirical results \\ support. We also find that buyers in the auction screen on CEO quality. Overall, labor market discipline is \\ dramatic, as filing CEOs suffer large income losses relative to CEOs of matched, non-bankrupt firms. \\ Firms emerging from auction bankruptcy appear healthy as they typically go on to perform at par with \\ industry rivals.
}

\section{Keywords}

bankruptcy, auctions, liquidation, restructuring, risk shifting, asset substitution, managerial conservatism, executive compensation, CEO turnover, post-bankruptcy performance

\section{Disciplines}

Economics | Finance | Finance and Financial Management

\section{Comments}

Author Karin S. Thorburn is a full time faculty member of Norwegian School of Economics. She is a visiting professor in the Finance Department of the Wharton School at the University of Pennsylvania. 


\title{
Control benefits and CEO discipline in automatic bankruptcy auctions*
}

\author{
B. Espen Eckbo and Karin S. Thorburn \\ Amos Tuck School of Business Administration \\ Dartmouth College \\ Hanover, NH 03755 \\ USA \\ March 2003 \\ forthcoming in the Journal of Financial Economics
}

\begin{abstract}
Swedish bankruptcy filing automatically terminates CEO employment and triggers an auction of the firm. Critics of this system warn of excessive shareholder risk-shifting incentives prior to filing. We argue that private benefits of control induce managerial conservatism that may override risk-shifting incentives. By investing conservatively, the $\mathrm{CEO}$ increases the joint probability that the auction results in a going-concern sale and that she is rehired. This uniquely implies that the rehiring probability is increasing in private control benefits, which our empirical results support. We also find that buyers in the auction screen on CEO quality. Overall, labor market discipline is dramatic, as filing CEOs suffer large income losses relative to CEOs of matched, non-bankrupt firms. Firms emerging from bankruptcy typically perform at par with industry rivals.
\end{abstract}

\footnotetext{
${ }^{*}$ We appreciate the comments of Kenneth Eades, Cliff Holderness, Edie Hotchkiss, Mark Huson, Michael Jensen, John Martin, Richard Ruback, and an anonymous referee of the journal. We have also received helpful suggestions by the seminar participants at Boston College, Georgetown University, Gothenburg University, and the Norwegian School of Economics and Business Administration, the Tuck CCG/JFE conference on Contemporary Corporate Governance Issues, the Utah Winter Finance Conference, and the annual meetings of the American Law and Economics Association, the Association of Financial Economists, and the European Finance Association. Partial financial support from the Swedish National Council for Crime Prevention (BRA)), and the Norwegian Research Council (NFR-grant no. 125105/510), is also gratefully acknowledged. Email: b.espen.eckbo@dartmouth.edu and karin.s.thorburn@dartmouth.edu.
} 


\section{Introduction}

Jensen and Meckling (1976) observe that the limited-liability feature of equity provides an incentive for shareholders to substitute high-risk for low-risk projects during financial distress. In this paper, we focus on the risk-shifting incentives of managers, not just of shareholders. Risk shifting requires active participation of the chief executive officer (CEO), and we argue that the CEO may actually prefer to invest conservatively in order to protect her private benefits of control. We explore this argument in the context of bankruptcy filings in Sweden, where a filing summarily terminates managerial employment contracts and places the firm in an open auction. The hard constraint on management in this automatic auction system has caused several authors, including Aghion, Hart, and Moore (1992), White (1996), and Hart (2000), to warn of excessive risk shifting prior to filing. However, our empirical analysis, which explores the notion of managerial conservatism, suggest that this warning is premature.

While risk shifting may be close to a free option for shareholders of an insolvent firm, "going for broke" increases the chance that the CEO loses her job. Our key argument is that, when the CEO derives private benefits from control, she has an incentive to invest conservatively to hedge against unfavorable bankruptcy outcomes. These unfavorable outcomes include outright company liquidation, where the CEO position is eliminated, or reorganization as a going concern with another CEO at the helm. Conversely, by investing conservatively, the CEO increases the chance of firm survival and, hence, of being rehired by the buyer in the auction. Thus, we argue that the existence of private control benefits creates a manager-shareholder conflict of interest during severe distress, which counteracts risk shifting. Moreover, we show that this conflict arises even if the manager owns a large equity stake in the firm.

Our focus on private benefits of control and the implication for managerial conservatism complements the traditional analysis of contractual arrangements designed to regulate risk shifting incentives. As documented in Smith and Warner (1979), contractual arrangements include debt covenants prohibiting certain forms of asset dispositions, such as merger, sale-leaseback, and asset collateralization. Risk-shifting incentives are also reduced by the use of convertible debt in

the firm's capital structure [e.g., Green (1984)]. Moreover, in countries such as Sweden and the United States, the legal code to some extent requires company directors to shift their fiduciary 
responsibility towards bondholders when approaching bankruptcy [e.g., Gilson (1990)].

The notion that managerial incentives can produce a conservative investment policy is not new. A substantial theoretical literature shows that managerial concern with reputational capital can induce conservatism. ${ }^{1}$ Our contribution is to associate conservatism with the existence of managerial private benefits of control, and to empirically examine incentive effects of control benefits in a setting where they are likely to be highly relevant for the firm's investment choices. Our argument is made interesting by the fact that, while reputational capital is specific to the individual CEO, private benefits of control are largely firm-specific. Furthermore, private benefits are generally noncontractible and thus nontransferrable, except through the outright purchase of corporate control. For example, a potentially important private benefit is the power to hide incompetence and low work effort. Other examples of non-contractible private benefits are community prestige, perquisite consumption, and various forms of wealth expropriation. In general, the incentive effect of such control benefits differs from that of managerial reputational capital, which leads us to target both in the empirical analysis below.

A key prediction of the managerial conservatism hypothesis is that the probability of the CEO being rehired to run the restructured firm increases in her control benefits. Our empirical analysis distinguishes between inside and outside buyers in the auction, where the former represents a saleback to the old owner. Controlling for managerial quality, the key prediction is supported for inside buyers. For outside buyers, we find that the rehiring probability is increasing in managerial quality and is independent of CEO control benefits. The finding that buyers screen on CEO quality suggests that building a reputation for quality increases the expected value of the CEO's control benefits. If CEO quality and control benefits are in fact complementary, this incentive structure counteracts a tendency for private control benefits to induce value-reducing managerial entrenchment.

We also find that bankruptcy filing results in a severe labor market disciplining of the CEO. Using tax return information, which reflects income from all sources (not just wage), we show a large decline in CEO income. The median income loss is $-47 \%$ after controlling for the contemporaneous income change of CEOs of nonbankrupt industry rival firms of similar size. For outside buyers,

\footnotetext{
${ }^{1}$ See, for example, Fama (1980), Harris and Holmstrom (1982), Holmstrom and Ricart I Costa (1986), Diamond (1989), Gibbons and Murphy (1992), Brander and Poitevin (1992), Hirshleifer and Thakor (1992), and Zwiebel (1995).
} 
and controlling for CEO quality, the income decline increases in CEO control benefits, possibly reflecting a concern with entrenchment. Our evidence of a large ex post settling-up effect in the CEO's wage is consistent with the argument of Fama (1980) that the CEO will tend toward firmvalue maximization ex ante. ${ }^{2}$

Finally, we estimate post-bankruptcy performance of the auctioned firms. A high-risk strategy of "going for broke" arguably results in a stripped-down firm if it fails. The firm may have lost key employees and assets. Given that none of the sample firms is publicly traded, we use operating profitability and bankruptcy refiling rates to indicate the economic health of the firm's operations. The firms sold as going-concerns appear healthy as they typically perform at par with their industry rivals in the post-bankruptcy period. ${ }^{3}$ We also show that the bankruptcy refiling probability decreases with CEO control benefits and quality. Overall, our performance evidence indicates that buyers in the auction successfully screen on CEO quality, and it fails to support the risk-shifting hypothesis.

The rest of the paper is organized as follows. In Section 2, we model CEO investment incentives during periods of severe financial distress and analyze the conditions under which control benefits induce managerial conservatism. This section also develops the paper's main testable hypotheses. Data sources and sample characteristics are described in Section 3. Section 4 presents our empirical analysis, and Section 5 concludes the paper.

\section{Auction bankruptcy and managerial conservatism}

The CEOs of our sample firms typically own a substantial proportion of the equity (average $56 \%$, median 60\%, discussed below). Thus, we model CEO incentives as emanating from a combination of equity ownership, fixed wage, and private benefits of control. We first discuss our key proposition concerning the CEO's incentive to invest conservatively, and then summarize our main empirical test strategy.

\footnotetext{
${ }^{2}$ This evidence complements the literature on CEO compensation changes and turnover in financially distressed firms in the United States. See, for example, Gilson (1989), Gilson and Vetsuypens (1993), and Hotchkiss (1995).

${ }^{3}$ This finding contrasts with the evidence in Hotchkiss (1995) and Alderson and Betker (1999), which shows that public firms emerging from Chapter 11 bankruptcy in the United States systematically underperform their industry peers.
} 


\subsection{Control benefits and investment incentives}

The analysis concerns how private control benefits affect managerial investment incentives. Approaching bankruptcy, management may decide to maximize shareholder value by substituting high-risk for low-risk assets, increasing the volatility of the firm's asset value (riskshifting). However, since riskshifting also increases the downside risk of the firm, it increases the exposure of the CEO to loss of private control benefits. Following bankruptcy filing, the CEO retains private control benefits only if the firm survives bankruptcy and she is rehired by the buyer in the auction. Control benefits are lost either if the firm is liquidated or if the buyer selects another CEO. Thus, in contrast to shareholders, the CEO values the bankruptcy outcome in which the firm is sold as

a going concern. Consequently, the CEO may prefer a more conservative investment policy than shareholders to preserve firm survival and hedge private control benefits.

Proposition summarizes this intuition, and lists key determinants of managerial conservatism which are the focus of our empirical analysis:

Proposition 1 (Managerial conservatism) Suppose the CEO enjoys private benefits of control. Following bankruptcy, the CEO maintains control benefits only if the firm survives as a going concern and she is rehired. This generates an incentive for the CEO to invest conservatively - relative to the preferred investment policy of shareholders - to reduce the probability of the piecemeal liquidation outcome.

The likelihood of managerial conservatism increases with the value of private control benefits, the rehiring probability, the probability of the piecemeal liquidation outcome in the high-risk project relative to the low-risk project, and the degree of debt impairment. Moreover, the likelihood of managerial conservatism decreases with the CEO wage decline from bankruptcy filing and the CEO's equity ownership in the firm.

We illustrate Proposition 1 with a simple model of a firm in financial distress. The firm has debt outstanding with face value $F$ due next period. It has only three assets, $I$ dollars in cash and access to two investment projects $L$ (low risk) and $H$ (high risk), each requiring an initial investment of I today. The two projects have different outcome probability distributions but identical outcomes next period. Fig. 1 summarizes the key characteristics of the two projects. Each project requires an initial investment of $I$ today and returns next period a cash flow in three states of $C \in\{0, c, 2 c\}$, 
where $c>I$. Let $2 c>F>c$, so that the firm faces bankruptcy in both the low and intermediate states. The bankruptcy auction results in piecemeal liquidation of the firm in the low state $(C=0)$, and sale as a going concern in the intermediate state $(C=c)$. Bankruptcy costs are zero so that the buyer in the competitive auction pays $c$ for the firm in the intermediate state.

The probability distribution over the three cash flow states, $\operatorname{Pr}[C]$, is

$$
\operatorname{Pr}_{i}[C]= \begin{cases}{[p, 1-2 p, p]} & \text { for } i=L \\ {[p+a, 1-2 p-(a+b), p+b]} & \text { for } i=H\end{cases}
$$

Assuming risk neutrality and a discount rate normalized to zero, the value of project $L$ is positive $\left(N P V_{L}=c-I>0\right)$. Moreover, let $a>b>0$ so that the return distribution of project $H$ has both a higher variance and a lower expected value than the distribution of project $L$. Thus, $N P V_{L}-N P V_{H}=(a-b) c>0$, and the firm-value maximizing (efficient) investment policy is to accept project $L$. In other words, in this setting, riskshifting entails selecting the lower-value project. ${ }^{4}$ Let $S_{L}$ and $S_{H}$ denote the expected payoff to shareholders of the two projects, respectively. With limited liability, shareholders ignore the insolvency states, and $S_{L}=p(2 c-F)$ and $S_{H}=$ $(p+b)(2 c-F)$. Thus, $S_{H}>S_{L}$, and shareholders prefer the low-value but riskier project. ${ }^{5}$

The CEO leaves the firm in the low state, stays on in the high state, and is rehired with probability $\alpha$ in the intermediate state. As long as she remains with the firm, the CEO derives private benefits of control equal to $\beta$ dollars. Her compensation is also a function of the fraction $\tau \in[0,1]$ she owns of the firm's equity and of the wage decline $\gamma$ dollars resulting from the negative reputational signal of a bankruptcy filing. Here, $\gamma=w_{h}-w_{l}>0$, where $w_{h}$ is the CEO's wage in the high (nonbankruptcy) state, and $w_{l}$ is the wage in the two bankruptcy states. The assumption that the managerial labor market views a going-concern sale and a piecemeal liquidation as equivalent signals of CEO quality is for convenience only. If the labor market in fact reacts more negatively to a piecemeal liquidation than to a going-concern sale, then the incentives for managerial conservatism increases.

\footnotetext{
${ }^{4}$ Our assumption that $N P V_{L}>N P V_{H}$ is not critical. Project $H$ could also be a mean-preserving spread of project $L$ (i.e., $a=b$ so that the two projects have equal $N P V$ ) without changing the key results below. Our scenario where $N P V_{L}>N P V_{H}$ highlights the potentially damaging effects of riskshifting on total firm value.

${ }^{5}$ If $S_{L}<I$, shareholders will invest only if legal rules or the firm's debt contracts prohibit a liquidating dividend of $I$.
} 
With this notation, the CEO selects the project that maximizes the total expected payoff $E(\Pi)=E(\beta)+E(w)+\tau S$, where

$$
E_{i}(\Pi)= \begin{cases}w_{l}+p \gamma+p \beta+(1-2 p) \alpha \beta+\tau S_{L} & \text { for } i=L \\ \left.w_{l}+(p+b) \gamma+(p+b) \beta+(1-2 p-a-b) \alpha \beta+\tau S_{H}\right) & \text { for } i=H .\end{cases}
$$

Managerial conservatism follows when $\Delta \equiv E_{L}(\Pi)-E_{H}(\Pi)>0$; i.e., when

$$
\Delta=\alpha\left(\frac{a}{b}+1\right)-\frac{\gamma+\tau(2 c-F)}{\beta}-1>0 .
$$

Eq. (3) illustrates the partial effects listed in Proposition 1. First, $\partial \Delta / \partial \beta=[\gamma+\tau(2 c-F)] / \beta^{2}>0$; i.e., the incentive to invest conservatively is increasing in the private benefits of control $\beta$. Second, $\partial \Delta / \partial \alpha=a / b+1>0$. The intuition is that, the greater the rehiring probability $\alpha$, the more valuable (to the $\mathrm{CEO}$ ) is the intermediate state, which has the highest probability of occurring under project $L$. Third, $\partial \Delta / \partial(a / b)=\alpha>0$, because the high-risk project's probability of piecemeal liquidation increases with $a / b$. Increasing the ratio $a / b$ is akin to increasing the volatility of the value of the firm. Hence the benefit of a conservative investment strategy designed to hedge control benefits against the liquidation outcome. Fourth, $\partial \Delta / \partial F=\tau / \beta>0$. As the face value $F$ increases, $2 c-F$ decreases and the firm's debt becomes more impaired, decreasing the payoff to shareholders in the nonbankruptcy state. This reduces the value of project $H$ relative to $L$ and thus reduces the cost of managerial conservatism. Fifth, $\partial \Delta / \partial \gamma=-1 / \beta<0$. The greater the managerial wage decline $\gamma$ from bankruptcy, the greater value the CEO place on the solvency state and the greater the attractiveness of project $H$.

Finally, $\partial \Delta / \partial \tau=-(2 c-F) / \beta<0$. Ceteris paribus, the greater the equity stake $\tau$ held by the CEO, the greater the incentive alignment between the CEO and outside shareholders, as expected. However, even if $\tau$ is large, the total incentive effect of the equity stake remains small for a deeply distressed firm. In our framework, deep distress means that $2 c-F$ is small, so that even a large value of $\tau$ has a small effect on $\Delta$. The intuition is as follows. Suppose financial distress is the result of a negative shift in the firm's investment opportunity set, moving the high investment outcome $2 c$ close to the face value $F$. The same shift in the investment opportunity set limits shareholders' risk-shifting opportunities, increasing the scope for private control benefits to be the 
primary determinant of managerial investment policy.

The model can be generalized to make the rehiring probability $\alpha$ and the wage decline $\gamma$ functions of CEO-specific characteristics such as managerial quality reputation and degree of managerial entrenchment. For example, in Stulz (1988), a large CEO equity stake reduces firm value because the manager prefers to retain private control benefits over receiving a takeover premium, effectively deterring outside bids for control. In our data, the typical CEO owns a sufficient amount of equity to block bids for control. In the context of our bankruptcy filings, however, the CEO is automatically fired and cannot block the auction, regardless of the magnitude of $\tau$. Also, the buyer is free to optimally restructure the firm's governance system. Nevertheless, it is possible that a history of CEO entrenchment may be viewed negatively by external buyers and reduce both the CEO's wage offer (increase $\gamma$ ) and the rehiring probability $\alpha$ in the auction. We consider this possibility in the empirical analysis below.

\section{$2.2 \quad$ Hypotheses and empirical test strategy}

The model above explains how CEO incentives $\Delta$ to invest conservatively depends on factors such as the private benefits of control $\beta$, the rehiring probability $\alpha$, the wage loss $\gamma$ from bankruptcy filing, the CEOs equity ownership proportion $\tau$, and the severity of financial distress $2 c-F$. Absent data on either the investment incentives or the ex ante investment opportunity set (which determines $a / b)$, the direct effect of these variables on $\Delta$ cannot be estimated. Instead, we examine managerial conservatism through the lens of auxiliary hypotheses based on observable outcomes of bankruptcy filings. As before, the fundamental idea is that managerial conservatism promotes firm survival, and therefore survival of the CEO's control benefits, in bankruptcy.

We focus on the rehiring probability $\alpha$, the CEO wage loss $\gamma$, and post-bankruptcy firm performance. The last is represented by operating profitability $\pi$ and the bankruptcy refiling probability $\delta$. We employ cross-sectional regressions of the form

$$
y_{i}=f_{i}\left(\text { control }, \text { quality }, x_{i}\right), \quad i=\alpha, \gamma, \pi, \delta,
$$

where control and quality are empirical proxies for private benefits of control and the CEO's reputation for quality, respectively, and $x_{i}$ is a vector of additional control variables depending on 
which of the variable $y_{i}$ is being used. Thus, control and quality are factors common to all of the regressions. As explained in Section 4, both control and quality are constructed using a simple factor representation technique.

We subsume the effect of the two remaining model parameters, the managerial ownership fraction $\tau$ and the severity of financial distress $(2 c-F)$, in the factors control and quality. According to Proposition 1, even large values of $\tau$ have only a small manager-equityholder incentive alignment effect when the firm is in severe distress. Thus, we posit that the main effect of $\tau$ is to enhance private benefits of control, particularly when $\tau$ represents a controlling equity position in the firm.

Similarly, we assume that the primary role of the degree of financial distress is to affect the CEO's reputation for managerial quality. We proxy $2 c-F$ in part by the firm's ex post debt recovery rate, based on the price paid for the firm in the auction. The presumption is that a highly distressed firm tends to produce a low recovery in bankruptcy and that this low recovery rate reflects negatively on the CEO's quality reputation.

There are two distinct types of buyers in going-concern sales: Outside investors (external buyers) and old owners (internal buyers, including the CEO). When inside buyers win the auction, we refer to the outcome as a saleback. The greater the value of control, the greater the price the CEO is potentially willing to bid in a saleback, providing a competitive advantage over external buyers in the auction (see also the theoretical bidding analysis in Eckbo and Thorburn (2002)). Thus, there are a priori reasons to believe that private control benefits are on average larger in salebacks than for sales to external buyers. Our empirical hypotheses below exploits this intuition.

\section{Hypothesis 1 (Rehiring probability). (1) Larger control benefits induce greater} managerial conservatism and hence increase the probability that the firm survives as a going concern conditional on bankruptcy. (2) Conditional on a going-concern sale, larger control benefits increase the probability that the CEO will be rehired in a saleback but do not increase the probability of being rehired by an external buyer. (3) The rehiring probability is increasing in managerial quality reputation.

Combining (1) and (2) of Hypothesis 1, the greater the control benefits, the higher the probability of being rehired in a saleback than in a sale to an external buyer. Moreover, as a corollary, control benefits will be lowest for piecemeal liquidations. As to (3) in Hypothesis 1, external buyers clearly 
have an incentive to screen CEOs on quality. In a saleback, the incentive to screen on CEO quality comes not so much from the buyer (the CEO often rehires herself) but from outside investors asked to finance the transaction. To check this proposition, in addition to estimating Eq. (4), we compare the average interest charge in salebacks with that of going-concern sales to external buyers.

Hypothesis 2 (Wage loss). (1) Larger control benefits increase the risk of managerial entrenchment and hence increase the wage loss upon bankruptcy filing. (2) The wage loss associated with control benefits is greater for sales to external buyers than for salebacks.

(3) The wage loss is smaller the greater the CEO's reputation for managerial quality.

Because bankruptcies are rarely just a simple consequence of bad luck, the average bankruptcy filing is predicted to damage managerial reputation and result in a wage loss. Hypothesis 2 states that this wage loss is driven both by the level of private control benefits and CEO quality. While an external buyer offers the CEO a competitive wage rate, a saleback may allow the CEO to extract rents, thus (2) of the hypothesis. In our tests, we use data on all sources of CEO income, as listed in personal tax returns. Moreover, we benchmark the CEO income change using nonbankrupt firms matched on industry and size.

\section{Hypothesis 3 (Post-bankruptcy performance). Managerial conservatism reduces} risk shifting, preserves the firm's assets, and thus increases the firm's post-bankruptcy performance.

A failed risk-shifting strategy results in loss of assets and a depletion of going-concern value. By tempering risk-shifting incentives ex ante, managerial conservatism increases the likelihood that the firm, if it goes bankrupt, enters bankruptcy with its assets intact. This simplifies efforts to restructure the firm as a viable going concern. Absent data on either pre-filing asset dispositions or the true state of the bankrupt firm's assets (other than recovery rates), we explore this implication of managerial conservatism through post-bankruptcy performance measures such as operating performance and the probability of bankruptcy refiling. Because evidence of a strong post-bankruptcy accounting performance does not discriminate between managerial conservatism leading to a good asset base in bankruptcy and simply skilful restructuring of poor assets in the absence of conservatism, this analysis is exploratory in nature. ${ }^{6}$

\footnotetext{
${ }^{6}$ None of our sample firms is publicly traded, precluding a performance analysis using equity returns. Moreover,
} 


\section{Data sources and sample characteristics}

This section provides descriptive information on the characteristics of Swedish bankruptcy auctions, as well as of the filing firms and their CEOs. When filing for bankruptcy, all debt service is stayed, and a trustee is appointed by the court to run an open auction. The trustee normally hires an outside consultant or retains the incumbent CEO on a temporary basis to oversee the firm's operations until the sale is completed. Bids may be submitted for individual assets (piecemeal liquidation) or for the entire firm as a going concern. Bids must be in cash, and the proceeds are distributed strictly according to absolute priority. The auctions typically attract substantial bidder interest, and the entire process is swift, with an average of 2 months to completion. See Thorburn (2000) and Eckbo and Thorburn (2002) for comprehensive evidence on costs, duration, and bidding strategies in our Swedish bankruptcy auctions.

\subsection{Data sources}

We start by adding information on firm and CEO characteristics in the sample of 263 Swedish bankruptcy cases originally compiled by Thorburn (2000). The sample, which consists of bankruptcy filings between January 1, 1988 and December 31, 1991, is identified using the proprietary database of UpplysningsCentralen (UC). To be included, the filing firm must have at least 20 employees. There are a total of 1,159 firms in the UC database satisfying the above criteria. Of these, 581 firms are eliminated because the filing was in a remote geographical area, while another 315 cases are excluded for one of the following additional reasons: The case is still pending in bankruptcy as of June 30, 1995 (145 cases); there are tax fraud charges (59 cases); or the bankruptcy file is incomplete (111 cases). ${ }^{7}$ Of the 263 cases in the sample, 9 filings occurred in 1988, 27 in 1989, 71 in 1990, and 156 in 1991. The auction results in 200 firms sold as going concern, 60 piecemeal liquidations, while 3 cases have insufficient information to be classified by outcome. Throughout

a more complete performance analysis would condition on changes in the firm's asset structure in the period prior to bankruptcy, requiring data that are chronically hard to come by. As reported by, e.g., John, Lang, and Netter (1992), John and Ofek (1995), Andrade and Kaplan (1998), and DeAngelo, DeAngelo, and Wruck (2002), asset sales are common among distressed firms in the United States.

${ }^{7}$ The sample is limited to firms located in the four largest provinces in Sweden: Stockholms län, Göteborg- and Bohus län, Malmöhus län, and Upplands län. This restriction economizes on the cost of physical travel to each jurisdiction where bankruptcy files are stored. While the firm's assets are quickly auctioned off in bankruptcy, the old and empty corporate shell typically remains on file with the court for several years. This is a formality that has no implications for the sale of the firm's assets in the auction. 
the paper, a going-concern sale is defined as a joint sale of the assets that are essential for the firm's continued operations. Examples of such assets are inventory, machinery, vehicles, unfinished products, intangible assets, industrial estate, and rental contracts.

For each firm in the sample, we add information on firm- and case-specific characteristics identified from the public court record. For 260 firms, the identity of the incumbent CEO is found by matching information in the court records with UC-supplied information on board membership. UC also supplied financial statements from the period 1987-1995 for the entire Swedish population of 16,000 firms with at least 20 employees that were either operating on December 31, 1991 or pending in bankruptcy. We use this information to calculate industry median operating performance and distress measures.

From the UC database, we construct post-bankruptcy financial statements for 158 firms auctioned as a going concern. For 42 going-concern sales, we could not identify the firm postbankruptcy. Moreover, UC provides the individual tax returns for 258 of the sample firms' CEOs for the years 1988-1991 and 1993-1994. There are some limitations in the UC database: The 1990 and 1991 tax returns are available for a subset of 130 of the sample CEOs, while the 1992 tax returns is unavailable for all. For comparison purposes, tax returns for the period 1988-1994 are also obtained for a randomly selected sample of CEOs of 1,346 nonbankrupt Swedish firms with at least 20 employees.

\subsection{Sample characteristics}

Table 1 lists several key characteristics of the sample firms. All firms are privately held and small, with average sales of $\$ 5.0$ million, total assets (size) of $\$ 2.4$ million, and 43 employees. The small firm size is a general feature of the Swedish economy and not of our sampling procedure. The sample represents more than 30 two-digit standard industrial classification (SIC) groups. Twentynine percent (76) of the firms are in manufacturing industries, while another $13 \%$ (33 firms) are in the construction industry. Thirty firms are in the wholesale business, while there are 26 firms $(10 \%)$ in each of the hotel and restaurant industry and in the transportation industry.

Panel A of Table 1 lists selected financial characteristics for the sample firms. With the exception of the fraction secured debt, the source of this information is the last financial statement reported prior to the bankruptcy filing, which on average dates back 17.5 months (median 16.5 
months). As expected, the firms perform poorly prior to bankruptcy with an average operating profitability (EBITDA to total sales) of $-1 \%$ (median $2 \%$ ). Industry-adjusted, the operating profitability (profmarg) averages $-6 \%$ with a median of $-4 \%$, both significantly different from zero at the $1 \%$ level. Industry-adjusted means that we are subtracting the contemporaneous median operating profitability of all Swedish firms with at least 20 employees in the same four-digit SIC code as the sample firm. The average number of rival firms per industry used in this industry adjustment is 299 (median 273), with a minimum of 20. Also as expected, filing firms have high leverage ratios. The average ratio of total book debt to total book assets is $92 \%$ (median 93\%), and the average interest coverage ratio (EBITDA plus interest income divided by interest expense) is -2.3 (median $1.0)$.

Absent data on the market value of equity for the private firms, we use the fraction of secured debt (secured) as a proxy for the proportion tangible assets. This implicitly assumes that firms tend to lever up their tangible assets and that the cross-sectional variation in total leverage ratios is small. The fraction secured debt, which averages $39 \%$, is identified from the bankruptcy file. ${ }^{8}$ Thorburn (2000) shows that the greater the proportion of secured debt, the higher the probability of piecemeal liquidation. Eckbo and Thorburn (2002) find that auction premiums in excess of the piecemeal liquidation value of assets tend to be significantly lower the greater the fraction of secured debt. Both of these observations are consistent with greater secured debt being a proxy for lower going-concern value, which is what we want.

Panel B of Table 1 lists personal characteristics of the CEO. As indicated by the variable tenure, $65 \%$ of the filing CEOs have been employed as CEO for at least two years. In other words, over the two-year period prior to filing, 35\% of the CEOs are replaced. The firms exhibit concentrated share ownership, with a single shareholder typically controlling $50 \%$ or more of the equity. This controlling shareholder is often the CEO. As shown in the table, the average CEO equity ownership (ownership) is $57 \%$, with a median of $60 \% .{ }^{9}$ Furthermore, as shown in Fig. 2, the distribution of ownership is skewed with 88 CEOs (43\%) owning $100 \%$ of the firm's shares. Moreover, the CEOs of 50 firms (25\%) own no equity, with a fairly even distribution between $0 \%$ and $100 \%$. The typical

\footnotetext{
${ }^{8}$ The debt structure of our Swedish companies is typically simple: Approximately $90 \%$ of the secured debt is bank-debt; there are no firms with public debt; and basically all nonsecured claims have identical priority (with the exception of wages and taxes).

${ }^{9}$ We have information on CEO ownership for 205 of the 263 firms. Our CEO ownership data include the ownership of the CEO's spouse and children with the same last name. Such nonCEO family ownership is negligible.
} 
CEO is 20 years from retirement at the time of filing, with an average age (age) of 45 (median 46). Finally, based on the income tax return two years prior to filing, the average CEO total income before tax is $\$ 40,000 .{ }^{10}$ Thus, given the equity ownership information above, the typical CEO's wealth exposure to the equity value of the firm is substantial.

Panel $\mathrm{C}$ of Table 1 provides information on auction characteristics. Upon filing, the trustee is required to provide an estimate of when the firm became insolvent and could potentially have filed for bankruptcy. The variable delay, which is the number of months between this first insolvency date and the bankruptcy filing date, averages 4.8 months (median 4.0 months). That is, in the opinion of the trustee, the typical filing firm delayed filing by only four months. We believe that this relatively short delay undermines the notion of substantial risk-shifting and asset-stripping activities following severe financial distress in the filing firms. ${ }^{11}$

The trustee is required to provide an assessment of the reason for the bankruptcy filing. As shown in the table, the trustee concludes in $32 \%$ of the cases that the filing is a result of CEO incompetence or economic crime (inept). Below, we use this information, together with variables for filing delay, operating profitability, and debt recovery rate, to construct an empirical proxy for CEO reputation. The debt recovery rate in percent of the face value of total debt (recovery) averages $35 \%$ (median 33\%).

Finally, Panel D reports the degree of industry distress at the time of the sample bankruptcy filings (distress). Industry distress is defined as the fraction of firms in the four-digit industry of the filing firm that have an interest coverage ratio of less than one in the year of the filing or file for bankruptcy the following year. With this definition, on average $42 \%$ of firms in the industry are distressed (median 38\%). Thus, the typical firm in our sample files for bankruptcy at a time when a substantial number of its competitors are also financially distressed.

\section{Empirical Analysis}

In this section, we estimate the empirical model in Eq. (4) and use the coefficient estimates to test hypotheses 1 through 3 . We start with the construction of proxies for the variables control

\footnotetext{
${ }^{10}$ This exceeds the average per capita income in Sweden during the sample period, which is predominantly from 1988-1989. The sample maximum CEO income is $\$ 720,000$.

${ }^{11}$ Most firms in our sample file for bankruptcy after running out of liquidity and defaulting on their debt payments. In excess of $90 \%$ of the filings are made by the firm's management, with the remaining filed by a creditor.
} 
and quality. We then proceed with interpreting the regression results for the rehiring probability (Hypothesis 1), the CEO income loss (Hypothesis 2), and post-bankruptcy performance (Hypothesis $3)$.

\subsection{Factor representation of CEO quality and private control benefits}

Constructing proxies for control and quality is not straightforward. One approach is to include as explanatory variables a number of individual, observable characteristics that are believed to reflect quality and control aspects. This necessitates interpretation of a large number of individual regression coefficients of typically correlated characteristics, which is problematic. ${ }^{12}$ We instead implement a simple factor-analytic approach to summarize the information in the characteristics.

The construction of the factors control and quality goes as follows. First, we designate key characteristics, as defined in Table 1. Second, using generally available empirical evidence, as well as our own economic intuition, we determine a priori the coefficient on each characteristic to be either 1 or -1 . Third, we create a value for each of the two factors by summing the characteristics. The value of each characteristic falls in the range $|0,1|$, so that each has a commensurable impact on the total factor value. If the underlying characteristic itself does not fall in this range, then the characteristic is transformed, as indicated by un asterisk $\left(^{*}\right)$.

The factor control is constructed as the sum of four characteristics:

$$
\text { control }=\text { ownership }+ \text { tenure }- \text { secured }- \text { size } .
$$

Motivated by the discussion in Section 2, we constrain the characteristics ownership and tenure to enter with positive sign. Basically, the greater the ownership fraction and the longer the CEO's tenure, the greater the opportunity to extract private benefits. The positive sign for ownership is also motivated by studies documenting that CEO turnover in large U.S. corporations tends to decrease in managerial equity ownership, e.g., Ofek (1993), Denis and Denis (1994), Denis, Denis, and Sarin (1997), and Mikkelson and Partch (1997).

Moreover, we constrain control to decrease in asset tangibility (secured). As argued by Dyck and Zingales (2001) as well, it is more costly to expropriate tangible than intangible assets. Finally,

\footnotetext{
${ }^{12}$ We pursued this approach in an earlier version of this paper. The results are available upon request.
} 
the variable size* $=\left[\ln (\right.$ size $\left.)-\mu_{s}\right] / \sigma_{s}$, where $\mu_{s}$ and $\sigma_{s}$ are the mean and standard deviation of $\ln ($ size $)$, respectively, is constrained to have a negative sign. CEOs of smaller firms are often required to carry out a multitude of different tasks throughout the organization, which we conjecture provides a greater scope for extracting private control benefits. There is also substantial extant evidence that managerial turnover increases in firm size.

Turning to quality, we construct this factor using another set of four characteristics, all observable by the buyer in the auction:

$$
\text { quality }=\text { recovery }{ }^{*}+\text { profmarg }- \text { inept }- \text { delay* } .
$$

The positive sign for the transformed debt recovery rate, recovery ${ }^{*}=\sqrt{\text { recovery }}$, and for the industry-adjusted operating profitability, profmarg, is consistent with the evidence in, e.g., Warner, Watts, and Wruck (1988), Weisbach (1988), Morck, Shleifer, and Vishny (1989), and Mikkelson and Partch (1997) of a lower CEO turnover in high-performing firms. In addition to serving as an indicator of CEO quality, the variable recovery captures the quality of the bankrupt firm's assets. Under either interpretation, greater values of recovery* are assumed to increase the value of the factor quality. Finally, we constrain inept and delay* $=\sqrt{\text { delay }} / \sigma_{d}$, where $\sigma_{d}$ is the standard deviation of delay, to enter with a negative sign. The negative sign for delay* is intended to reflect that asset substitution, restructuring, and other capital-raising activities designed to stay out of bankruptcy are more time consuming for lower-quality CEOs.

\subsection{The CEO rehiring probability}

We have information on the rehiring outcome for 170 of the 200 sample firms sold as going concern. In this subsample, a total of 86 CEOs (51\%) are rehired. The rehiring rate is greater in salebacks than in sales to outside investors, $70 \%$ (79 of 112) versus $12 \%$ (7 of 58). ${ }^{13}$ Adding the sample of 60 piecemeal liquidations (where the CEO position is eliminated) to the going-concern sales, the total percentage rehired is $39 \%$, or a turnover rate of $61 \%$. This is similar to turnover rates reported by Gilson (1989) for Chapter 11 filings in the United States. Gilson reports that of the senior

\footnotetext{
${ }^{13}$ The decision to hire an outside CEO in a saleback typically coincides with the old owner not being the CEO. Also, the old CEO does not always own equity in the firm prior to bankruptcy and thus does not necessarily influence the rehiring decision in a saleback. See Fig. 2.
} 
managers in place in year $-2,45 \%$ remain in their positions at filing (year 0 ) while only $29 \%$ remain by year +2 (roughly coinciding with the time the firm emerges from Chapter 11 proceedings). See also the turnover evidence in Gilson and Vetsuypens (1993), LoPucki and Whitford (1993), Betker (1995), and Hotchkiss (1995).

We specify the rehiring probability $\alpha$ as a function of the factors quality and control and the two variables age and distress. As defined in Table 1, distress is the degree of industry wide financial distress. The factors control and quality are largely uncorrelated and are uncorrelated with the industry distress variable distress. This is partly a reflection of the fact that we have purged the median industry performance from profmarg. Moreover, separate regressions confirm that recovery, as well as each of the individual characteristics in control, are uncorrelated with industry distress variables. Thus, including control, quality, and distress on the right-hand side of the same regression does not induce multicollinearity.

Several U.S. studies, e.g., Weisbach (1988), Murphy and Zimmerman (1993), Mikkelson and Partch (1997), and Goyal and Park (2002), find that CEO age is a significant determinant of CEO turnover. Thus, we use the variable age to control for the CEO's age at filing. In our data, age is uncorrelated with the indicator variable tenure used to construct the factor control. Controlling for CEO quality and control benefits, the probability of rehiring is expected to be lower the closer the CEO is to retirement age.

The empirical model and sign predictions are as follows:

$$
\begin{aligned}
\alpha= & f \text { (control, quality, age, distress }) \\
& \frac{\partial \alpha}{\partial \text { control }}>0, \quad \frac{\partial \alpha}{\partial \text { quality }}>0, \quad \frac{\partial \alpha}{\partial a g e}<0, \quad \frac{\partial \alpha}{\partial \text { distress }}<0 .
\end{aligned}
$$

The coefficient values resulting from the probit estimation is shown in Table 2. The estimation is performed using two samples for which we have sufficient information on all the variables. The first is 112 going-concern sales, and the second adds 38 piecemeal liquidations for a total of 150 cases. We report two models. Model 1 uses the four explanatory variables in Eq. (7). Model 2 classifies the factors quality and control in going-concern sales according to whether the buyer in the auction is the old owner (saleback) or a company outsider (external), and it includes an interaction variable for piecemeal liquidations (piecemeal). 
The models in Table 2 have significant explanatory power, with pseudo- $R^{2}$ ranging from $8 \%$ (Model 1) to 30\% (Model 2). Several of the coefficient estimates are as predicted by Hypothesis 1. First, the coefficient for control is positive and significant (Model 1). Second, Model 2 shows that the positive effect of control is restricted to salebacks, indicating that the incentive of ownermanagers to repurchase the company is increasing in managerial control benefits. This result is predicted by managerial conservatism but not by risk-shifting arguments (where control benefits do not play a role).

Hypothesis 1 also predicts that outside buyers associate large control benefits with managerial entrenchment, which for a given value of quality lowers their incentive to rehire the CEO. Given the insignificant coefficient on control $*$ external, this prediction is not supported. The coefficient on control * piecemeal is significantly negative and significantly lower than for either control * saleback or control*external. Thus, managerial control benefits are on average lowest for piecemeal liquidations and perhaps too small for the old owner-manager to undertake a saleback of these firms. This evidence is also consistent with our basic theory that ex ante control benefits affect the bankruptcy outcome.

The variable quality is positive and significant at the $2 \%$ level or better in Model 1 , indicating that the buyers in the auction screen the old CEOs on quality before making the rehiring decision. As shown when using Model 2, the significance of quality reflects screening by the external (outside) buyer, while managerial quality is insignificant in a saleback to the old owner. This suggests that screening on CEO quality, while important to the outside buyer, is of secondary importance for an owner-manager, perhaps because she repurchases the company to preserve control benefits. However, as shown in Section 4.3, a lack of screening can be costly. Salebacks have typically higher cost of debt financing than sales to outside investors, possibly reflecting a perception among banks of lower average CEO quality in saleback transactions.

The coefficient on quality * piecemeal is insignificant. Given that the CEO is never rehired when the firm is liquidated, this suggests that the average CEO quality in firms that are liquidated is indistinguishable from the overall sample mean quality (conditional on Model 2). In other words, we cannot conclude that firms end up being liquidated (as opposed to purchased as going concerns) simply because of poor managerial quality. As discussed in Maksimovic and Phillips (1998), bankrupt firms divest their plants as a function of industry conditions. In our context, if 
bankruptcy is the result of declining product market demand, a decision to liquidate could be taken independently of CEO quality.

The industry distress variable, distress, receives a negative coefficient that is significant at the $7 \%$ level or better in all four model specifications. Industry distress could lower industry insiders' (the owner-manager or rival firms) interest in the auction. The lower the demand from industry insiders, the lower the probability that the CEO is rehired. Finally, the variable age is insignificant. This may be a reflection of the relatively young age of the CEOs in our sample (mean 45). Replacing age with a dummy variable for age 59 or older also produces an insignificant coefficient. Thus, although we would expect CEOs close to retirement age to leave the firm voluntarily following bankruptcy filing, this effect does not influence our coefficient estimates. ${ }^{14}$

In sum, the results in Table 2 provide support for the key prediction of Hypothesis 1: The CEO rehiring probability $\alpha$ increases with private benefits of control in salebacks. In addition, the rehiring probability increases with outside reputation for quality and decreases with industrywide distress.

\subsection{The CEO income loss}

In the model of Section 2, the parameter $\gamma$ represents the CEO's wage reduction from bankruptcy filing. Hypothesis 2 is, however, stated more broadly in terms of the CEO income loss from all sources. A loss of reputation may affect the CEO's external income as well, including outside fees from consultancy, board memberships, etc. This information is provided by the individual tax returns for a total of 258 of our sample CEOs. The tax returns also allow us to follow the CEO's income after she leaves the company, and we focus on the time series of income change over the event period year -3 through year 5 , where year 0 is the year of the bankruptcy filing.

We measure the rate of income change in two ways. The first uses data on the filing CEOs only and is computed as $\Delta c_{t}=\left(c_{t}-c_{t-1}\right) / c_{t-1}$, where $c_{t}$ is a CEO's net income before tax in year $t$. (Because capital losses are not deductible against salary income in Sweden, $\Delta c_{t}$ reflects the full salary loss of the CEO.) The second is the abnormal CEO's income change, measured relative to the contemporaneous CEO income change $\Delta d_{t}$ in a matched nonbankrupt firm of similar total

\footnotetext{
${ }^{14}$ As argued by Brickley, Linck, and Coles (1999), the labor market time horizon of CEOs could extend beyond formal retirement age. They find that greater CEO reputation (measured using firm performance) increases the likelihood of future board directorships.
} 
asset size and in the same four-digit SIC industry. The abnormal CEO income change is defined as $\Delta c_{t}^{*}=\Delta c_{t}-\Delta d_{t}$. The control firms are selected from the random population of 1,346 nonbankrupt firms described at the end of Section 3.1.

Fig. 3 provides a visual impression of the significant income difference that develops between filing and nonfiling CEO as of the year of bankruptcy filing. The figure plots an index of the annual taxable CEO income, denoted $\hat{c}_{t}$. The index value is normalized to 100 in year -3 and is computed as $\hat{c}_{t}=\hat{c}_{t-1} \Delta c_{t}^{m}$ for subsequent years, where $\Delta c_{t}^{m}$ is the sample median of $\Delta c_{t}$. The index value for nonfiling CEOs is computed the same way, with $d$ replacing $c$ everywhere. The top curve in the graph is the index value for the control sample of nonbankrupt firms, while the lower curve is the index value for the CEOs of bankrupt firms. As shown, the incomes of filing and nonfiling CEOs grow at approximately the same rate up until bankruptcy filing. Then, over the subsequent three years (year 0 through year 2), filing CEOs show a sharp income decline while nonfiling CEOs' income continues to grow at about the same rate as before. After year 2, the incomes of the two categories of CEOs again grow at similar rates. In other words, bankruptcy filing seems to produce a large and permanent income loss for the filing CEO relative to the top management of nonfiling industry competitors.

From inspection of Fig. 3, it is natural to focus on the event period from year -2 through year 3 as capturing the full income change differential between filing and nonfiling CEOs. The median and mean values of the abnormal income change $\Delta c_{-2,3}^{*}$ are $-47.0 \%$ and $-66.1 \%$, respectively. Using a nonparametric sign test for the median and a t-test for the mean, both numbers are significantly different from zero on a $1 \%$ level. As predicted, bankruptcy induces a statistically significant income loss for CEOs of filing firms, relative to the contemporaneous income change of CEOs of matched, nonbankrupt companies.

Next, we estimate a cross-sectional regression model for the income loss $\gamma \equiv \Delta c_{-2,3}$. Because Hypothesis 2 predicts that $\gamma$ depends on CEO control benefits, we use the same regression specification as for the rehiring model (Eq. 7 and Table 2):

$$
\begin{aligned}
\gamma= & f(\text { control, quality, age, distress }) \\
& \frac{\partial \gamma}{\partial \text { control }}>0, \quad \frac{\partial \gamma}{\partial \text { quality }}<0, \quad \frac{\partial \gamma}{\partial a g e}>0, \quad \frac{\partial \gamma}{\partial \text { distress }}>0 .
\end{aligned}
$$


The results are in Table 3. Because of data constraints on primarily the income variable, the regression employs a total of 114 cases, 85 going-concern sales and 29 liquidations. The regression models have low explanatory power, with adjusted $R^{2}$ for Model 2 of $4 \%$ and $6 \%$, respectively. With the exception of control, the regressors receive statistically insignificant coefficients. Thus, the income decline, while large and significant on average, does not depend on CEO quality, CEO age, or industry distress.

The coefficient on control is positive and significant for the subsample of going-concern sales (Model 1), with a $p$-value of $8 \%$. Thus, greater control benefits lowers the CEO's wage upon bankruptcy filing, possibly because high control benefits are associated with greater CEO entrenchment. This interpretation is reinforced by the significance of control * external, where the $p$-value is less than $2 \%$ in the total sample regression as well as in the regression based on the subsample of going-concern sales. In sum, the CEO income decline is greater when the firm is purchased by a company outsider, as predicted by Hypothesis 2 .

Hypothesis 2 also predicts that the CEO wage decline should occur for salebacks as well as for sales to outsiders. The median, industry-adjusted wage decline $\left(\Delta c_{-2,3}^{*}\right)$ is $-25 \%$ for salebacks and $-57 \%$ for sales to company outsiders, with the difference being statistically insignificant. Thus, retaining control through a saleback does not hedge against a CEO income decline. A possible reason for this wage decline is that the saleback firm is relatively cash-constrained because of higher cost of external (debt) financing given the potentially greater CEO entrenchment and lower CEO quality in salebacks. If so, the greater cost of debt constrains the CEO's ability to maintain her wage at the pre-bankruptcy level.

To gauge the role of outside financing costs, we compare interest expense across salebacks and sales to outsiders over the year following the auction. The ratio of interest expense to the face value of total debt averages $7.4 \%$ for salebacks and $5.3 \%$ for sales to outsiders, the difference being statistically significant at a 5\% level (two-tailed Wilcoxon signed-rank test). The source of this greater cost of debt is not greater leverage in salebacks. For year 1, the median leverage ratio (book total debt over book assets) is 0.90 for salebacks and 0.91 for nonsalebacks.

To our knowledge, this study is the first to document compensation changes of individual CEOs after they leave the firm. Gilson and Vetsuypens (1993) compare the compensation given old and new CEOs following distressed restructurings and Chapter 11 bankruptcy. They report that if the 
CEO is replaced by an outsider, the median new CEO receives a cash compensation (salary and bonus) that is $36 \%$ higher than her predecessor, indicating a substantial wage differential to a CEO untainted by bankruptcy and distress. Moreover, if the CEO is replaced by an insider with ties to the previous management, the new CEO receives on average $35 \%$ lower cash compensation than the outgoing CEO. Thus, CEOs involved in distressed reorganizations appear to experience significant compensation declines in both Sweden and the United States.

\subsection{Post-bankruptcy performance}

In this section, we report post-bankruptcy operating performance, leverage ratios, and bankruptcy refiling probabilities. This information helps gauge the likelihood that the firm is severely and irreversibly run down by prefiling risk shifting and asset stripping and whether the automatic auction process itself efficiently restructures the firm. As stated in Hypothesis 3, managerial conservatism reduces risk shifting and increases post-bankruptcy performance.

Post-bankruptcy performance estimation requires identification of the new restructured firm. Using information from the bankruptcy file and UC, a total of 158 of the going-concern sales could be identified post-bankruptcy. Of these, post-bankruptcy financial statements are available for 115 firms. Table 4 lists five performance and growth measures, adjusted for industry median, for this sample: Annual operating profitability (EBITDA/sales), sales growth, growth in total (book value) assets, the ratio of capital expenditure (change in property, plant, and equipment from last year plus the current year's depreciation) to total assets, and book value of total debt to total assets. The table reports median values with and without an adjustment for the industry median. The industry-adjusted value is the median of the difference between the firm and its median industry rival, where a rival is a firm with at least 20 employees in the same four-digit SIC industry as the bankrupt company.

Using a Wilcoxon signed-rank test, the median industry-adjusted operating profitability is indistinguishable from zero at a $5 \%$ level in each of the five years following bankruptcy, as predicted by Hypothesis 3. Computing operating profitability using total assets instead of sales produces identical inferences. By year 5, 63\% of the surviving sample firms perform better than the median industry benchmark firm. Moreover, the growth rates in sales and assets are at par with the respective industry medians. The growth rate series start in year 1 as no financial statement is 
available for the restructured firm in the year of the auction; i.e., year 0 .

The level of capital expenditures is significantly above the industry median in year 2 (the first year of measurement) and converges to the industry level by year 3. Also, the auctioned firms emerge more highly leveraged than their industry rivals (median debt/assets of 0.90 versus 0.80 in year 1), and they tend to stay highly leveraged through year 4 . While not shown in Table 4 , the relatively high debt level is also reflected in a lower than industry interest coverage ratio. Overall, the information in Table 4 indicates that firms emerging as going concerns from auction bankruptcy are more highly levered but perform, grow, and invest at the level of their industry rivals. Studying firms emerging from Chapter 11, Gilson (1997) also finds that debt levels remain high.

Next, we ask whether the industry-adjusted operating profitability $\pi_{t}$ cumulated over years $t=1$ and $t=2$ are affected by our quality and control factors, using the following regression model:

$$
\begin{aligned}
e^{\sum_{1}^{t} \pi_{t}}= & f(\text { control, quality, distress, merger }), \quad t=1,2, \\
& \frac{\partial e^{\sum_{1}^{t} \pi_{t}}}{\partial \text { control }}>0, \quad \frac{\partial e^{\sum_{1}^{t} \pi_{t}}}{\partial \text { quality }}>0, \quad \frac{\partial e^{\sum_{1}^{t} \pi_{t}}}{\partial \text { distress }}<0, \quad \frac{\partial e^{\sum_{1}^{t} \pi_{t}}}{\partial \text { merger }}>0 .
\end{aligned}
$$

Here, merger is a dummy variable indicating that the buyer in the auction merged the bankrupt firm into another going concern (and not into an empty corporate shell). Approximately one-third of the going-concern sales were merged into an existing going concern. The variable merger controls for possible synergy effects of the acquiror's existing assets. We focus on years 1 and 2 only, as the impact of the prefiling characteristics in control and quality on the subsequent performance of the restructured firm are greatest in the early years.

We use Eq. (9) to investigate whether the cross-sectional variation in the old CEOs control benefits and quality help explain the auctioned firms' industry-adjusted operating profitability. Under Hypothesis 3, high-quality managers with high control benefits exhibit conservatism in their pre-bankruptcy choices. Coupled with effective screening by the (external) buyer in the auction, the presumption is that this conservatism makes it easier to restructure the firm and run it in a profitable manner post-bankruptcy. Thus, a corollary of Hypothesis 3 is that the industry-adjusted operating performance is increasing in control and quality. 
The results are in Table 5. Because of data constraints on post-bankruptcy financial statements, the regression employs a total of 66 going-concern sales. The adjusted $R^{2}$ ranges from $4 \%$ (Model 2) to $10 \%$ (Model 1). The factor control is insignificant in all four models. However, quality receives a significantly positive coefficient in year 1 (Model 1), which is consistent with Hypothesis 3. Model 2 in year 1 shows that the significance of quality is greatest in the sample of salebacks. This result is intuitive because, in our framework (and supported by the results in Table 2), there is more extensive screening on CEO quality when the buyer is external. Effective screening tends to eliminate the cross-sectional correlation between quality (measured using the pre-bankruptcy CEOs) and subsequent post-bankruptcy performance within the sample of firms sold to external buyers. Conversely, with less screening in the sample of salebacks, the resulting wider distribution of CEO qualities in this sample produces a significant coefficient estimate on quality. Table 5 also shows that the cumulative performance over years 1 and 2 is increasing in the variable is merger. That is, merging the bankrupt firm with the buyer's assets appears to improve the subsequent two-year industry-adjusted operating performance.

Finally, we examine our second measure of post-bankruptcy performance: the likelihood $\delta$ that the restructured firm is forced to refile for bankruptcy. Again, pre-bankruptcy managerial conservatism is predicted to increase survival; i.e., to reduce the refiling probability. In our sample of 158 identified post-bankruptcy firms, a total of 39 (25\%) refile for bankruptcy within two years, and 59 (37\%) within five years. The median time to refiling is 20 months (average 23). These refiling rates are higher than the 19\% five-year filing frequency for the overall population of Swedish firms with 20 employees or more over the same time period. ${ }^{15}$ Table 6 estimates, using the explanatory variables in Eq. (9), the probability of refiling for 94 going-concern sales over 1, 2, and 3 years following bankruptcy. ${ }^{16}$ The probit regressions are significant for years 2 and 3 (Chi-square test) with values of the pseudo- $R^{2}$ ranging from $9 \%$ (Model 1) to $13 \%$ (Model 2). The insignificance of the year 1 regression is not surprising given the proximity to the auction itself (the median refiling firm files in 20 months).

Focusing on the year 2 regression (the results are similar for year 3), greater values for both

\footnotetext{
${ }^{15}$ The source of the general filing rate is Statistics Sweden. Our sample period covers a severe business downturn in the fall of 1991, causing the annual bankruptcy filing rate for firms with at least 20 employees in Sweden to peak at $6 \%$ in 1992.

${ }^{16}$ The sample size is up from 66 in Table 5 as the regressions in Table 6 do not require post-bankruptcy financial statements. We also ran the estimation for years 4 and 5 , with similar results.
} 
control and quality lower the probability of refiling. The significance of control in Model 2, year 2, is predominantly driven by the subsample of external buyers. External buyers have a greater incentive to screen on CEO quality, which by itself improves post-bankruptcy performance. The significance of control * external further implies that, within the sample of external buyers, the greater the private benefits of control, the lower the chance of refiling. This is consistent with Hypothesis 3 where greater control benefits leads to greater pre-bankruptcy managerial conservatism, which in turn improves the firm's chance of long-term survival. Also, as with the earlier regression on operating performance, the significance of quality is driven by the subsample of salebacks. The intuition for this result is identical to the one given above for Table 5: There is more extensive screening of CEO quality when the buyer is external, eliminating the correlation between quality and subsequent post-bankruptcy performance. ${ }^{17}$

Overall, the evidence in Tables 4-6 indicates that the typical restructured firm performs at par with its industry rivals. The operating performance increases in quality, while the refiling probability is decreasing in both quality and control. These findings are consistent with the joint hypothesis of managerial conservatism ex ante and efficient screening on CEO quality in the auction. The evidence provides little support for the alternative view that the auction bankruptcy system induces costly risk-shifting and asset-stripping activities to avoid bankruptcy.

In contrast to our findings for Swedish small-firm bankruptcies, Hotchkiss (1995) reports that a sample of 197 public firms emerging from Chapter 11 significantly underperform industry rivals over a five-year post-bankruptcy period. Moreover, operating profitability suffers, and bankruptcy refiling probability is increased, when the reorganized firm retains the old management. (In her sample, $32 \%$ of the firms refile for bankruptcy or initiate a private debt workout within five years.) Overall, she finds little evidence to support the hypothesis that distressed firms are effectively rehabilitated in Chapter 11.

\section{Conclusions}

We present a simple model demonstrating that CEO private benefits of control complement managerial reputation, compensation schemes, and financial contracts in counteracting costly shareholder

\footnotetext{
${ }^{17}$ As shown in an earlier version of the paper, the refiling probability does not depend on whether the auctioned firm is run by the old CEO or an outsider.
} 
risk-shifting incentives during financial distress. The implied managerial conservatism in project selection attenuates agency costs of debt and benefits shareholders ex ante. We take this model to a sample of bankruptcy filings in Sweden, where a filing summarily terminates managerial employment contracts and automatically puts the firm up for auction. The hard constraint on management makes this an ideal laboratory for examining the opposing theories of risk shifting and managerial conservatism prior to filing. While we do not have data on specific prefiling project choices or asset substitutions, the theory predicts that managerial concern with maintaining private benefits of control will manifest itself in the buyer's decision to rehire the CEO, the CEO income loss from filing, and the post-bankruptcy performance of the restructured firm.

Our empirical analysis employs two factors representing private benefits of control and CEO quality reputation. The factors, which are constructed using a set of characteristics that are observable to the buyer in the bankruptcy auction, turn out to significantly determine the CEO rehiring probability, as predicted. Greater levels of control benefits increase the probability of a saleback of the firm to the old owner-manager. Moreover, we find that the probability that an external buyer will rehire the manager increases with the manager's quality reputation. Thus, the greater the managerial quality, the greater the expected value of her private control benefits. This incentive structure tends to alleviate concerns that private control benefits also promote managerial entrenchment.

Using personal tax returns (publicly available in Sweden), we also are able to track the CEO's income after she leaves the firm. We find that a bankruptcy filing is a costly event: The median CEO income change around bankruptcy is $-47 \%$ in excess of the contemporaneous income change for a control sample of CEOs of nonbankrupt firms matched on industry and firm size. The income loss of a filing CEO does not vary with our CEO quality factor. Thus, it does not appear that high-quality CEOs avoid the wrath of the labor market following bankruptcy filing. Conditional on $\mathrm{CEO}$ quality, the $\mathrm{CEO}$ income loss increases with the factor measuring private benefits of control provided the buyer is a company outsider. Thus, outside buyers tend to screen CEOs using estimates of both CEO quality and private control benefit.

We also find that the firms emerging from the bankruptcy auction perform well. Post-bankruptcy operating profitability is at par with (healthy) industry rivals in every year over a five-year period following the auction. The firms' growth rates in sales and total assets and in capital expenditures 
are at par or above that of industry rivals. We also find that the post-bankruptcy operating performance increases in our CEO quality factor. Greater control benefits and CEO quality reduces the probability that the firm will refile for bankruptcy over the years following the initial filing, suggesting reduced prefiling risk shifting.

Overall, our results indicate that a bankruptcy filing in the Swedish automatic auction system is costly for the filing $\mathrm{CEO}$ and that the probability of the CEO maintaining her position depends on publicly available information about control benefits and quality. We conclude that the ex ante incentive effects of the managerial labor market transaction caused by bankruptcy filing help explain why the firms emerging from the bankruptcy auctions as going concerns are economically healthy. There is no empirical support for the alternative hypothesis that CEOs systematically run down distressed firms by means of costly risk-shifting and asset-stripping strategies to stay out of bankruptcy. 


\section{References}

Aghion, Philippe, Oliver Hart, and John Moore, 1992, The economics of bancruptcy reform, Journal of Law, Economics and Organization 8, 523-546.

Alderson, Michael J., and Brian L. Betker, 1999, Assessing post-bankruptcy performance: An analysis of reorganized firm's cash flows, Financial Management 28, 62-82.

Andrade, Gregor, and Steven N. Kaplan, 1998, How costly is financial (not economic) distress? Evidence from highly leveraged transactions that became distressed, Journal of Finance 53, 1443-1493.

Betker, Brian L., 1995, An empirical examination of prepackaged bankruptcy, Financial Management 24, 3-18.

Brander, James A., and Michel Poitevin, 1992, Managerial compensation and the agency costs of debt finance, Managerial and Decision Economics 13, 55-64.

Brickley, James A., James S. Linck, and Jeffrey L. Coles, 1999, What happens to CEOs after they retire? New evidence on career concerns, horizon problems, and CEO incentives, Journal of Financial Economics 52, 341-377.

DeAngelo, Harry, Linda DeAngelo, and Karen H. Wruck, 2002, Asset liquidity, debt covenants, and managerial discretion in financial distress: The collapse of L.A. Gear, Journal of Financial Economics 64, 3-34.

Denis, David J., and Diane K. Denis, 1994, Majority owner-managers and organizational efficiency, Journal of Corporate Finance 1, 91-118.

, and Atulya Sarin, 1997, Agency problems, equity ownership, and corporate diversification, Journal of Finance 52, 135-160.

Diamond, Douglas W., 1989, Reputation acquisition in debt markets, Journal of Political Economy $97,828-862$.

Dyck, Alexander, and Luigi Zingales, 2001, Private benefits of control: An international comparison, Working paper, Harvard Business School.

Eckbo, B. Espen, and Karin S. Thorburn, 2002, Overbidding vs. fire-sales in bankruptcy auctions, Working Paper 02-04, Tuck School of Business at Dartmouth.

Fama, Eugene F., 1980, Agency problems and the theory of the firm, Journal of Political Economy $88,288-307$.

Gibbons, Robert, and Kevin J. Murphy, 1992, Optimal incentive contracts in the presence of career concerns: Theory and evidence, Journal of Political Economy 100, 468-505.

Gilson, Stuart, and Michael Vetsuypens, 1993, CEO compensation in financially distressed firms, Journal of Finance 48, 425-458.

Gilson, Stuart C., 1989, Management turnover and financial distress, Journal of Financial Economics 25, 241-262. 
— , 1990, Bankruptcy, boards, banks, and blockholders: Evidence on changes in corporate ownership and control when firms default, Journal of Financial Economics 27, 355-387.

— 1997, Transactions costs and capital structure choice: Evidence from financially distressed firms, Journal of Finance 52, 161-196.

Goyal, Vidhan K., and Chul W. Park, 2002, Board leadership structure and CEO turnover, Journal of Corporate Finance 8, 49-66.

Green, Richard C., 1984, Investment incentives, debt, and warrants, Journal of Financial Economics 13, 115-136.

Harris, Milton, and Bengt Holmstrom, 1982, A theory of wage dynamics, Review of Economic Studies 49, 315-333.

Hart, Oliver, 2000, Different approaches to bankruptcy, Working paper, Harvard University, MA.

Hirshleifer, David, and Anjan V. Thakor, 1992, Managerial conservatism. project choice, and debt, Review of Financial Studies 5, 437-470.

Holmstrom, Bengt, and Joan Ricart I Costa, 1986, Managerial incentives and capital management, Quarterly Journal of Economics 100, 835-860.

Hotchkiss, Edith S., 1995, Post-bankruptcy performance and management turnover, Journal of Finance 50, 3-21.

Jensen, Michael C., and William Meckling, 1976, Theory of the firm: Managerial behavior, agency costs, and capital structure, Journal of Financial Economics 3, 305-360.

John, Kose, Larry H.P. Lang, and Jeffery Netter, 1992, The voluntary restructuring of large firms in response to performance decline, Journal of Finance 47, 891-917.

John, Kose, and Eli Ofek, 1995, Asset sales and increase in focus, Journal of Financial Economics $37,105-126$.

LoPucki, Lynn, and W. Whitford, 1993, Corporate governance in the bankruptcy reorganization of large, publicly held companies, University of Pennsylvania Law Review 141, 669-800.

Maksimovic, Vojislav, and Gordon Phillips, 1998, Asset efficiency and reallocation decisions of bankrupt firms, Journal of Finance 53, 1495-1532.

Mikkelson, Wayne, and Megan Partch, 1997, The decline of takeovers and disciplinary managerial turnover, Journal of Financial Economics 44, 205-228.

Morck, Randall, Andrei Shleifer, and Robert W. Vishny, 1989, Alternative mechanisms for corporate control, American Economic Review 79, 842-852.

Murphy, Kevin J., and Jerold L. Zimmerman, 1993, Financial performance surrounding CEO turnover, Journal of Accounting and Economics 16, 273-315.

Ofek, Eli, 1993, Capital structure and firm response to poor performance: An empirical analysis, Journal of Financial Economics 34, 3-30.

Smith, Jr., Clifford W., and Jerold B. Warner, 1979, On financial contracting: An analysis of bond covenants, Journal of Financial Economics 7, 117-161. 
Stulz, Rene, 1988, Managerial control of voting rights: Financing policies and the market for corporate control, Journal of Financial Economics 20, 25-54.

Thorburn, Karin S., 2000, Bankruptcy auctions: Costs, debt recovery, and firm survival, Journal of Financial Economics 58, 337-368.

Warner, Jerold B., Ross L. Watts, and Karen H. Wruck, 1988, Stock prices and top management changes, Journal of Financial Economics 20, 461-492.

Weisbach, Michael S., 1988, Outside directors and ceo turnover, Journal of Financial Economics $20,431-460$.

White, Michelle, 1996, The cost of corporate bankruptcy: A U.S.-European comparison, in Jagdeep Bhandari, and Lawrence Weiss, ed.: Corporate Bankruptcy: Economic and Legal Perspectives . chap. 30, pp. 467-500 (Cambridge University Press).

Zwiebel, Jeffrey, 1995, Corporate conservatism and relative compensation, Journal of Political Economy 103, 1-25. 
Table 1

Prefiling and auction characteristics for privately held Swedish firms filing for auction bankruptcy, 1988-1991.

Characteristic $\begin{gathered}\text { Variable } \\
\text { name }\end{gathered}$ Mean \begin{tabular}{c} 
Median $\begin{array}{c}\text { Standard } \\
\text { error of the } \\
\text { mean }\end{array}$ \\
\hline
\end{tabular}

\section{A. Prefiling firm characteristic ${ }^{a}$}

Sales in millions of dollars

Bookvalue of assets in millions of dollars

Number of employees

Operating profitability

Industry-adjusted operating profitabilityc

Debt-to-assets ratio ${ }^{\mathrm{d}}$

Interest-coverage ratio

Proportion secured debt of total debt

\section{B. Chief executive officer (CEO) characteristic}

CEOs tenure exceeds two years (dummy) ${ }^{\mathrm{f}}$

Fraction CEO equity ownership in the filing firms

CEO age at filing

Prefiling income in thousands of dollarsh

\section{Auction characteristic}

Delay from insolvency to filing in months ${ }^{\mathrm{i}}$

CEO deemed incompetent by trustee (dummy)

Debt recovery rate as a fraction of face value

\section{Industry characteristic}

Industry distress $j$

\begin{tabular}{lccc} 
& 5.0 & 2.7 & 0.453 \\
size & 2.4 & 1.3 & 0.225 \\
& 43 & 29 & 2.793 \\
\multirow{4}{*}{ profmarg } & -0.01 & 0.02 & 0.009 \\
& -0.06 & -0.04 & 0.008 \\
& 0.92 & 0.93 & 0.013 \\
secured & -2.32 & 1.02 & 2.198 \\
& 0.39 & 0.38 & 0.153
\end{tabular}

$\begin{array}{llll}\text { tenure } & 0.65 & 1.00 & 0.030 \\ \text { ownership } & 0.57 & 0.60 & 0.030 \\ \text { age } & 45.1 & 46.0 & 0.456 \\ & 39.7 & 26.0 & 5.062\end{array}$

$\begin{array}{lccc}\text { delay } & 4.8 & 4.0 & 0.330 \\ \text { inept } & 0.32 & 0.00 & 0.029 \\ \text { recovery } & 0.35 & 0.33 & 0.013\end{array}$

distress

0.42

0.38

0.010

a The firm characteristics are from the financial statement last filed prior to bankruptcy filing, dated back on average 17.5 months (median 16.5 months), with exception of secured, which is from the bankruptcy file.

b Operating profitability is EBITDA divided by total sales.

c The firm's operating profitability less the contemporaneous median operating profitability for all Swedish firms with 20 employees or more, and the same four-digit industry code as the sample firm. The mean (t-test) and median (Wilcoxon signed-rank test) are significantly different from 0 at the $1 \%$ level.

d Book value of total debt divided by the book value of total assets.

e EBITDA plus interest income divided by interest expense.

${ }^{\mathrm{f}}$ Fraction of CEOs in office two years prior to filing who are still in office at the time of bankruptcy filing. g CEO equity ownership includes ownership of spouses.

$\mathrm{h}$ Net income before tax two years prior to filings, as reported in the CEO's individual tax return.

I The delay is based on the trustee's estimate of when the firm became insolvent.

j Industry distress is the fraction of all Swedish firms with at least 20 employees and the same four-digit standard industrial classification (SIC) code as the sample firm that either reports an interest coverage ratio of less than one in the year of filing, or files for bankruptcy during the next calendar year. 
Table 2

Determinants of the chief executive officer (CEO) rehiring probability in the bankruptcy auction The table shows the coefficient estimates in the probit regressions for the probability $\alpha$ that the buyer in the auction rehires the incumbent CEO. The probability $\alpha$ is modeled as a function of the two factors control and quality, as well as the control variables age and distress:

$$
\alpha=f \text { (control, quality, age, distress). }
$$

The dependent variable in the probit regression is a binary variable that takes on the value of 1 if the CEO is rehired and 0 otherwise. The factor control is a proxy for managerial private benefits of control, and the factor quality measures CEO quality, defined using the following CEO and firm characteristics:

and

$$
\text { control } \equiv \text { ownership }+ \text { tenure }- \text { secured }- \text { size* }
$$

$$
\text { quality } \equiv \text { recovery* }+ \text { profmarg }- \text { inept }- \text { delay*. }
$$

The characteristics for the factor control are defined as follows: ownership is percent CEO equity holding, tenure is a binary variable indicating that the CEO's tenure with the firm exceeds two years, secured is the fraction of total debt that is secured, and size $=\left[\ln (\operatorname{size})-\mu_{s}\right] / \sigma_{s}$, where size is the prefiling book value of assets and $\mu_{\mathrm{s}}$ and $\sigma_{\mathrm{s}}$ are the mean and standard deviation of $\ln (\operatorname{size})$, respectively. The characteristics for the factor quality are defined as follows: recovery* is the square root of the creditor recovery rate recovery, profmarg is the firm's industry-adjusted operating profitability, inept is a binary variable indicating that the bankruptcy trustee classified the CEO as incompetent, and delay* is the square root of delay divided by its standard deviation, where delay is the number of months from the trustee's estimate of the insolvency date to the firm's filing date. Moreover, saleback and external are binary variables indicating that the auctioned firm is sold as a going concern to the old owner and to a company outsider, respectively. The binary variable piecemeal indicates that the assets of the bankrupt firm are sold piecemeal in the auction. The variable age is the CEO's age at filing, and distress is the degree of industrywide distress (see Table 1 for details). The sample is composed of 150 privately held Swedish firms filing for bankruptcy during 1988-1991 ( $p$-values are in parentheses). 


\begin{tabular}{|c|c|c|c|c|}
\hline \multirow[b]{2}{*}{ Explanatory variable } & \multicolumn{2}{|c|}{ Going concern sales } & \multicolumn{2}{|c|}{ All filings } \\
\hline & Model 1 & Model 2 & Model 1 & Model 2 \\
\hline Constant & $\begin{array}{c}-0.04 \\
(0.966)\end{array}$ & $\begin{array}{c}0.68 \\
(0.546)\end{array}$ & $\begin{array}{c}-0.09 \\
(0.914)\end{array}$ & $\begin{array}{c}0.16 \\
(0.870)\end{array}$ \\
\hline \multicolumn{5}{|l|}{ CEO control benefits } \\
\hline control & $\begin{array}{c}0.31 \\
(0.015)\end{array}$ & & $\begin{array}{c}0.25 \\
(0.022)\end{array}$ & \\
\hline control* $^{*}$ saleback & & $\begin{array}{c}0.55 \\
(0.000)\end{array}$ & & $\begin{array}{c}0.67 \\
(0.000)\end{array}$ \\
\hline control ${ }^{*}$ external & & $\begin{array}{c}-0.14 \\
(0.543)\end{array}$ & & $\begin{array}{l}-0.01 \\
(0.963)\end{array}$ \\
\hline 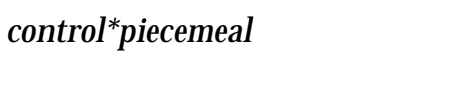 & & & & $\begin{array}{l}-0.82 \\
(0.022)\end{array}$ \\
\hline \multicolumn{5}{|l|}{ CEO quality reputation } \\
\hline quality & $\begin{array}{c}0.48 \\
(0.018)\end{array}$ & & $\begin{array}{c}0.43 \\
(0.013)\end{array}$ & \\
\hline quality*saleback & & $\begin{array}{c}0.22 \\
(0.349)\end{array}$ & & $\begin{array}{c}0.14 \\
(0.550)\end{array}$ \\
\hline quality ${ }^{*}$ external & & $\begin{array}{c}1.42 \\
(0.011)\end{array}$ & & $\begin{array}{c}1.46 \\
(0.012)\end{array}$ \\
\hline quality*piecemeal & & & & $\begin{array}{c}1.33 \\
(0.126)\end{array}$ \\
\hline age & $\begin{array}{c}0.01 \\
(0.581)\end{array}$ & $\begin{array}{c}-0.00 \\
(0.936)\end{array}$ & $\begin{array}{c}0.01 \\
(0.628)\end{array}$ & $\begin{array}{c}0.01 \\
(0.963)\end{array}$ \\
\hline \multicolumn{5}{|l|}{ Industry control } \\
\hline distress & $\begin{array}{c}-1.39 \\
(0.066)\end{array}$ & $\begin{array}{c}-1.79 \\
(0.031)\end{array}$ & $\begin{array}{l}-1.60 \\
(0.015)\end{array}$ & $\begin{array}{c}-2.02 \\
(0.009)\end{array}$ \\
\hline Sample size & 112 & 111 & 150 & 149 \\
\hline $\begin{array}{l}\text { Number of cases where } \\
\text { the CEO is rehired }\end{array}$ & 56 & 56 & 56 & 56 \\
\hline Pseudo $R$-square & 0.08 & 0.21 & 0.08 & 0.30 \\
\hline$\chi^{2}$ statistic for regression & $\begin{array}{c}12.7 \\
(0.013)\end{array}$ & $\begin{array}{c}32.9 \\
(0.000)\end{array}$ & $\begin{array}{c}15.2 \\
(0.004)\end{array}$ & $\begin{array}{c}59.2 \\
(0.000)\end{array}$ \\
\hline
\end{tabular}


Table 3

Determinants of the chief executive officer (CEO) income loss around auction bankruptcy filing The table reports the ordinary least squares coefficient estimates in cross-sectional regressions of the CEO income loss $\gamma=\log \left(c_{-2} / c_{3}\right)$, where $c_{t}$ is the CEO's income before tax in year $t$ relative to the filing year $(t=0)$. The income loss $\gamma$ is modeled as a function of the two factors control and quality, as well as the control variables age and distress:

$$
\gamma=f \text { (control, quality, age, distress). }
$$

The factor control is a proxy for managerial private benefits of control, and the factor quality measures $\mathrm{CEO}$ quality, defined using the following $\mathrm{CEO}$ and firm characteristics:

and

$$
\text { control } \equiv \text { ownership }+ \text { tenure }- \text { secured }- \text { size* }
$$

$$
\text { quality } \equiv \text { recovery* }+ \text { profmarg }- \text { inept }- \text { delay*. }
$$

The characteristics for the factor control are defined as follows: ownership is percent CEO equity holding, tenure is a binary variable indicating that the CEO's tenure with the firm exceeds two years, secured is the fraction of total debt that is secured, and size ${ }^{*}=\left[\ln (\operatorname{size})-\mu_{s}\right] / \sigma_{s}$, where size is the prefiling book value of assets and $\mu_{\mathrm{s}}$ and $\sigma_{\mathrm{s}}$ are the mean and standard deviation of $\ln (\operatorname{size})$, respectively. The characteristics for the factor quality are defined as follows: recovery* is the square root of the creditor recovery rate recovery, profmarg is the firm's industry-adjusted operating profitability, inept is a binary variable indicating that the bankruptcy trustee classified the CEO as incompetent, and delay* is the square root of delay divided by its standard deviation, where delay is the number of months from the trustee's estimate of the insolvency date to the firm's filing date. Moreover, saleback and external are binary variables indicating that the auctioned firm is sold as a going concern to the old owner and to a company outsider, respectively. The binary variable piecemeal indicates that the assets of the bankrupt firm are sold piecemeal in the auction. The variable age is the CEO's age at filing, and distress is the degree of industrywide distress (see Table 1 for details). The sample is composed of 114 privately held Swedish firms filing for bankruptcy 1990-1991 ( $p$-values are in parentheses). 


\begin{tabular}{|c|c|c|c|c|}
\hline \multirow[b]{2}{*}{ Explanatory variable } & \multicolumn{2}{|c|}{ Going concern sales } & \multicolumn{2}{|c|}{ All filings } \\
\hline & Model 1 & Model 2 & Model 1 & Model 2 \\
\hline constant & $\begin{array}{l}-1.36 \\
(0.164)\end{array}$ & $\begin{array}{l}-1.23 \\
(0.215)\end{array}$ & $\begin{array}{l}-1.09 \\
(0.200)\end{array}$ & $\begin{array}{c}-1.00 \\
(0.200)\end{array}$ \\
\hline \multicolumn{5}{|l|}{ CEO control benefits } \\
\hline control & $\begin{array}{c}0.23 \\
(0.079)\end{array}$ & & $\begin{array}{c}0.12 \\
(0.297)\end{array}$ & \\
\hline control*saleback & & $\begin{array}{c}0.09 \\
(0.572)\end{array}$ & & $\begin{array}{c}0.03 \\
(0.823)\end{array}$ \\
\hline control $^{*}$ external & & $\begin{array}{c}0.46 \\
(0.019)\end{array}$ & & $\begin{array}{c}0.47 \\
(0.008)\end{array}$ \\
\hline control $^{*}$ piecemeal & & & & $\begin{array}{c}-0.28 \\
(0.144)\end{array}$ \\
\hline \multicolumn{5}{|l|}{ CEO quality reputation } \\
\hline quality & $\begin{array}{c}0.16 \\
(0.457)\end{array}$ & & $\begin{array}{c}0.06 \\
(0.354)\end{array}$ & \\
\hline quality*saleback & & $\begin{array}{c}0.19 \\
(0.467)\end{array}$ & & $\begin{array}{c}0.19 \\
(0.416)\end{array}$ \\
\hline quality*external & & $\begin{array}{c}0.02 \\
(0.951)\end{array}$ & & $\begin{array}{c}0.05 \\
(0.889)\end{array}$ \\
\hline quality*piecemeal & & & & $\begin{array}{c}0.18 \\
(0.616)\end{array}$ \\
\hline age & $\begin{array}{c}0.02 \\
(0.319)\end{array}$ & $\begin{array}{c}0.02 \\
(0.426)\end{array}$ & $\begin{array}{c}0.02 \\
(0.354)\end{array}$ & $\begin{array}{c}0.01 \\
(0.448)\end{array}$ \\
\hline \multicolumn{5}{|l|}{ Industry control } \\
\hline distress & $\begin{array}{c}0.59 \\
(0.486)\end{array}$ & $\begin{array}{c}0.82 \\
(0.348)\end{array}$ & $\begin{array}{c}0.60 \\
(0.381)\end{array}$ & $\begin{array}{c}0.93 \\
(0.160)\end{array}$ \\
\hline Sample size & 85 & 83 & 114 & 111 \\
\hline Adjusted $R$-square & 0.02 & 0.04 & -0.01 & 0.06 \\
\hline $\begin{array}{l}F \text { statistic for } \\
\text { regression }\end{array}$ & $\begin{array}{c}1.38 \\
(0.249)\end{array}$ & $\begin{array}{c}1.54 \\
(0.177)\end{array}$ & $\begin{array}{c}0.75 \\
(0.600)\end{array}$ & $\begin{array}{c}1.84 \\
(0.077)\end{array}$ \\
\hline
\end{tabular}


Table 4

Five-year post-bankruptcy performance, growth, and leverage for 115 private Swedish firms auctioned in bankruptcy as going concerns, 1988-1991.

\begin{tabular}{|c|c|c|c|}
\hline & & Firm value & Industry-adjusted value \\
\hline Event year ta & Sample size & Fraction $<0$ & Fraction $<0$ \\
\hline
\end{tabular}

\section{A. Operating profitability (EBITDA/sales)}

$\begin{array}{rrrrrr}1 & 111 & 0.054 & 0.23 & 0.005 & 0.49 \\ 2 & 103 & 0.043 & 0.21 & -0.007 & 0.54 \\ 3 & 88 & 0.064 & 0.16 & -0.003 & 0.52 \\ 4 & 85 & 0.079 & 0.15 & 0.001 & 0.47 \\ 5 & 45 & 0.096 & 0.11 & 0.020^{* * *} & 0.37\end{array}$

B. Growth in sales

$\begin{array}{lrrrcc}{[1,2]} & 104 & 0.015 & 0.48 & 0.027 & 0.48 \\ {[2,3]} & 88 & 0.076 & 0.32 & 0.029^{* * *} & 0.45 \\ {[3,4]} & 81 & 0.111 & 0.27 & 0.060 & 0.43 \\ {[4,5]} & 45 & 0.040 & 0.42 & -0.030 & 0.59\end{array}$

\section{C.: Growth in total book assets}

$\begin{array}{lrrrrr}{[1,2]} & 103 & 0.022 & 0.48 & 0.011 & 0.47 \\ {[2,3]} & 89 & 0.029 & 0.43 & -0.002 & 0.51 \\ {[3,4]} & 83 & 0.077 & 0.36 & 0.010 & 0.48 \\ {[4,5]} & 46 & 0.054 & 0.46 & -0.023 & 0.52\end{array}$

\section{Capital expenditure/assets ${ }^{c}$}

$\begin{array}{llllll}{[1,2]} & 99 & 0.000 & 0.47 & 0.008 & 0.48 \\ {[2,3]} & 84 & 0.000 & 0.34 & 0.020 & 0.48 \\ {[3,4]} & 76 & 0.000 & 0.43 & -0.036 & 0.59 \\ {[4,5]} & 40 & 0.000 & 0.35 & -0.045^{\text {** }} & 0.69\end{array}$

\section{E. Total book debt-to-assets ratio}

$\begin{array}{rrrrr}1 & 111 & 0.902 & 0.105^{*} & 0.28 \\ 2 & 105 & 0.895 & 0.088^{*} & 0.27 \\ 3 & 90 & 0.877 & 0.094^{*} & 0.32 \\ 4 & 87 & 0.832 & 0.093^{*} & 0.36 \\ 5 & 46 & 0.760 & -0.001 & 0.50\end{array}$

a Year $\mathrm{t}=1$ denotes the first year of operations following the bankruptcy auction.

b Industry-adjusted median is the median difference between the firm and the median value for its industry rivals, where industry rivals are all Swedish firms with 20 employees or more and the same four-digit standard industrial classification code as the sample firm. The probability of rejecting the null hypothesis that the industry-adjusted value equals zero at the $1 \%, 5 \%$, and $10 \%$ significance level is denoted ${ }^{*}, *$, and $* * *$, respectively, using a two-tailed Wilcoxon singed-rank test.

c Capital expenditure is the difference in book value of property, plant, and equipment from last year plus this year's depreciation. 
Table 5

Determinants of the post-bankruptcy industry-adjusted operating profitability following auction bankruptcy

The table shows coefficient estimates for ordinary least squares regressions of the postbankruptcy industry-adjusted operating profitability $\pi_{\mathrm{t}}$ cumulated over years $t=1$ and $t=2$, where year 0 is the year of the bankruptcy auction. $\pi_{\mathrm{t}}$ is defined as the difference between the firm's operating profitability (EBITDA/sales) and the contemporaneous median operating profitability for all Swedish firms with at least 20 employees and the same four-digit standard industrial classification code. The cumulative operating profitability is modeled as a function of the two factors control and quality, as well as the control variables distress and merger:

$$
\left.e^{\sum_{1}^{t} \pi_{t}}=\text { f(control, quality, distress, merger }\right), \quad t=1,2 .
$$

The factor control is a proxy for managerial private benefits of control, and the factor quality measures chief executive officer (CEO) quality, defined using the following CEO and firm characteristics:

and

$$
\text { control } \equiv \text { ownership }+ \text { tenure }- \text { secured }- \text { size }
$$

$$
\text { quality } \equiv \text { recovery* }+ \text { profmarg }- \text { inept }- \text { delay*. }
$$

The characteristics for the factor control are defined as follows: ownership is percent CEO equity holding, tenure is a binary variable indicating that the CEO's tenure with the firm exceeds two years, secured is the fraction of total debt that is secured, and size ${ }^{*}=\left[\ln (\operatorname{size})-\mu_{s}\right] / \sigma_{s}$, where size is the prefiling book value of assets and $\mu_{s}$ and $\sigma_{s}$ are the mean and standard deviation of $\ln (\operatorname{size})$, respectively. The characteristics for the factor quality are defined as follows: recovery* is the square root of the creditor recovery rate recovery, profmarg is the firm's industry-adjusted operating profitability, inept is a binary variable indicating that the bankruptcy trustee classified the CEO as incompetent, and delay* is the square root of delay divided by its standard deviation, where delay is the number of months from the trustee's estimate of the insolvency date to the firm's filing date. Moreover, saleback and external are binary variables indicating that the auctioned firm is sold as a going concern to the old owner and to a company outsider, respectively. The binary variable piecemeal indicates that the assets of the bankrupt firm are sold piecemeal in the auction. Finally, distress is the degree of industrywide distress (see Table 1 for details), and the binary variable merger indicates that the buyer in the auction merged the bankrupt firm's assets into another going concern (and not into an empty corporate shell). The sample is composed of 66 privately held Swedish firms auctioned as a going concern, 1988-1991 ( $p$-values are in parentheses). 


\begin{tabular}{|c|c|c|c|c|}
\hline \multirow[b]{3}{*}{ Explanatory variable } & \multicolumn{4}{|c|}{ Dependent variable: industry-adjusted operating profitability $\pi$} \\
\hline & \multicolumn{2}{|c|}{ Year 1: $e^{\pi_{1}}$} & \multicolumn{2}{|c|}{ Year 1 and 2: $e^{\pi_{1}+\pi_{2}}$} \\
\hline & Model 1 & Model 2 & Model 1 & Model 2 \\
\hline constant & $\begin{array}{c}1.04 \\
(0.000)\end{array}$ & $\begin{array}{c}1.04 \\
(0.000)\end{array}$ & $\begin{array}{c}1.07 \\
(0.000)\end{array}$ & $\begin{array}{c}1.06 \\
(0.000)\end{array}$ \\
\hline \multicolumn{5}{|l|}{ CEO control benefits } \\
\hline control & $\begin{array}{c}-0.01 \\
(0.405)\end{array}$ & & $\begin{array}{l}-0.05 \\
(0.163)\end{array}$ & \\
\hline control*saleback & & $\begin{array}{c}-0.01 \\
(0.585)\end{array}$ & & $\begin{array}{l}-0.03 \\
(0.467)\end{array}$ \\
\hline control*external & & $\begin{array}{c}-0.02 \\
(0.466)\end{array}$ & & $\begin{array}{l}-0.08 \\
(0.135)\end{array}$ \\
\hline \multicolumn{5}{|l|}{ CEO quality reputation } \\
\hline quality & $\begin{array}{c}0.06 \\
(0.050)\end{array}$ & & $\begin{array}{c}0.08 \\
(0.182)\end{array}$ & \\
\hline quality*saleback & & $\begin{array}{c}0.08 \\
(0.043)\end{array}$ & & $\begin{array}{c}0.09 \\
(0.277)\end{array}$ \\
\hline quality*external & & $\begin{array}{c}0.03 \\
(0.587)\end{array}$ & & $\begin{array}{c}0.03 \\
(0.784)\end{array}$ \\
\hline \multicolumn{5}{|l|}{ Industry control } \\
\hline distress & $\begin{array}{c}-0.07 \\
(0.534)\end{array}$ & $\begin{array}{c}-0.06 \\
(0.565)\end{array}$ & $\begin{array}{c}-0.09 \\
(0.699)\end{array}$ & $\begin{array}{l}-0.07 \\
(0.752)\end{array}$ \\
\hline merger & $\begin{array}{c}0.05 \\
(0.121)\end{array}$ & $\begin{array}{c}0.05 \\
(0.167)\end{array}$ & $\begin{array}{c}0.19 \\
(0.014)\end{array}$ & $\begin{array}{c}0.21 \\
(0.014)\end{array}$ \\
\hline Sample size & 66 & 66 & 60 & 60 \\
\hline Adjusted $R$-square & 0.06 & 0.04 & 0.10 & 0.07 \\
\hline $\begin{array}{l}F \text { statistic of } \\
\text { regression }\end{array}$ & $\begin{array}{c}2.11 \\
(0.090)\end{array}$ & $\begin{array}{c}1.51 \\
(0.192)\end{array}$ & $\begin{array}{c}2.66 \\
(0.042)\end{array}$ & $\begin{array}{c}1.82 \\
(0.135)\end{array}$ \\
\hline
\end{tabular}


Table 6

Determinants of the bankruptcy refiling probability

The table shows the coefficient estimates for probit regressions of the probability $\delta_{t}$ that the firm refiles for bankruptcy within $t$ years of the original bankruptcy auction, where $t=[1,2,3]$. The refiling probability $\delta_{t}$ is modeled as a function of the two factors control and quality, as well as the control variables distress and merger:

$$
\delta_{\mathrm{t}}=f \text { (control, quality, distress, merger) }, \quad t=1,2,3 .
$$

The dependent variable in the probit regression is a binary variable that takes on the value of 1 if the firm refiles within $t$ years of the bankruptcy auction and 0 otherwise. The factor control is a proxy for managerial private benefits of control, and the factor quality measures CEO quality, defined using the following $\mathrm{CEO}$ and firm characteristics:

and

$$
\text { control } \equiv \text { ownership }+ \text { tenure }- \text { secured }- \text { size }
$$

$$
\text { quality } \equiv \text { recovery* }+ \text { profmarg }- \text { inept }- \text { delay*. }
$$

The characteristics for the factor control are defined as follows: ownership is percent CEO equity holding, tenure is a binary variable indicating that the CEO's tenure with the firm exceeds two years, secured is the fraction of total debt that is secured, and size ${ }^{*}=\left[\ln (\operatorname{size})-\mu_{s}\right] / \sigma_{s}$, where size is the prefiling book value of assets and $\mu_{\mathrm{s}}$ and $\sigma_{\mathrm{s}}$ are the mean and standard deviation of $\ln (\operatorname{size})$, respectively. The characteristics for the factor quality are defined as follows: recovery* is the square root of the creditor recovery rate recovery, profmarg is the firm's industry-adjusted operating profitability, inept is a binary variable indicating that the bankruptcy trustee classified the CEO as incompetent, and delay* is the square root of delay divided by its standard deviation, where delay is the number of months from the trustee's estimate of the insolvency date to the firm's filing date. Moreover, saleback and external are binary variables indicating that the auctioned firm is sold as a going concern to the old owner and to a company outsider, respectively. The binary variable piecemeal indicates that the assets of the bankrupt firm are sold piecemeal in the auction. Finally, distress is the degree of industrywide distress (see Table 1 for details), and the binary variable merger indicates that the buyer in the auction merged the bankrupt firm's assets into another going concern (and not into an empty corporate shell). The sample is composed of 94 privately held Swedish firms auctioned as a going concern, 1988-1991 ( $p$-values are in parentheses). 


\begin{tabular}{|c|c|c|c|c|c|c|}
\hline \multirow[b]{3}{*}{ Explanatory variable } & \multicolumn{6}{|c|}{ Dependent variable: bankruptcy refiling within t years } \\
\hline & \multicolumn{2}{|c|}{$t=1$} & \multicolumn{2}{|c|}{$t=2$} & \multicolumn{2}{|c|}{$t=3$} \\
\hline & Model 1 & Model 2 & Model 1 & Model 2 & Model 1 & Model 2 \\
\hline constant & $\begin{array}{c}-1.83 \\
(0.003)\end{array}$ & $\begin{array}{c}-2.03 \\
(0.003)\end{array}$ & $\begin{array}{l}-1.57 \\
(0.001)\end{array}$ & $\begin{array}{c}-1.73 \\
(0.000)\end{array}$ & $\begin{array}{c}-1.36 \\
(0.001)\end{array}$ & $\begin{array}{l}-1.52 \\
(0.001)\end{array}$ \\
\hline \multicolumn{7}{|l|}{ CEO control benefits } \\
\hline control & $\begin{array}{c}0.11 \\
(0.585)\end{array}$ & & $\begin{array}{c}-0.26 \\
(0.074)\end{array}$ & & $\begin{array}{c}-0.20 \\
(0.145)\end{array}$ & \\
\hline control*saleback & & $\begin{array}{c}0.22 \\
(0.297)\end{array}$ & & $\begin{array}{l}-0.15 \\
(0.347)\end{array}$ & & $\begin{array}{c}-0.09 \\
(0.546)\end{array}$ \\
\hline control*external & & $\begin{array}{c}-0.37 \\
(0.442)\end{array}$ & & $\begin{array}{c}-0.66 \\
(0.026)\end{array}$ & & $\begin{array}{c}-0.59 \\
(0.031)\end{array}$ \\
\hline \multicolumn{7}{|c|}{ CEO quality reputation } \\
\hline quality & $\begin{array}{c}-0.52 \\
(0.105)\end{array}$ & & $\begin{array}{l}-0.46 \\
(0.061)\end{array}$ & & $\begin{array}{c}-0.51 \\
(0.027)\end{array}$ & \\
\hline quality*saleback & & $\begin{array}{c}-0.83 \\
(0.032)\end{array}$ & & $\begin{array}{l}-0.63 \\
(0.028)\end{array}$ & & $\begin{array}{c}-0.66 \\
(0.016)\end{array}$ \\
\hline quality*external & & $\begin{array}{c}0.22 \\
(0.832)\end{array}$ & & $\begin{array}{l}-0.39 \\
(0.472)\end{array}$ & & $\begin{array}{c}-0.61 \\
(0.219)\end{array}$ \\
\hline \multicolumn{7}{|l|}{ Industry control } \\
\hline distress & $\begin{array}{c}0.37 \\
(0.753)\end{array}$ & $\begin{array}{c}0.36 \\
(0.773)\end{array}$ & $\begin{array}{c}2.09 \\
(0.019)\end{array}$ & $\begin{array}{c}2.23 \\
(0.017)\end{array}$ & $\begin{array}{c}2.03 \\
(0.018)\end{array}$ & $\begin{array}{c}2.20 \\
(0.014)\end{array}$ \\
\hline merger & $\begin{array}{c}0.50 \\
(0.913)\end{array}$ & $\begin{array}{c}0.46 \\
(0.386)\end{array}$ & $\begin{array}{c}0.18 \\
(0.602)\end{array}$ & $\begin{array}{c}0.45 \\
(0.241)\end{array}$ & $\begin{array}{c}0.19 \\
(0.562)\end{array}$ & $\begin{array}{c}0.43 \\
(0.231)\end{array}$ \\
\hline Sample size & 94 & 94 & 94 & 94 & 94 & 94 \\
\hline $\begin{array}{l}\text { Number of } \\
\text { cases where } \\
\text { firm refiles }\end{array}$ & 8 & 8 & 25 & 25 & 35 & 32 \\
\hline Pseudo $R$-square & 0.06 & 0.15 & 0.09 & 0.13 & 0.09 & 0.13 \\
\hline $\begin{array}{l}\chi^{2} \text { statistic for } \\
\text { regression }\end{array}$ & $\begin{array}{c}3.54 \\
(0.472)\end{array}$ & $\begin{array}{c}8.15 \\
(0.227)\end{array}$ & $\begin{array}{c}10.2 \\
(0.037)\end{array}$ & $\begin{array}{c}14.15 \\
(0.025)\end{array}$ & $\begin{array}{c}11.8 \\
(0.026)\end{array}$ & $\begin{array}{c}15.6 \\
(0.016)\end{array}$ \\
\hline
\end{tabular}




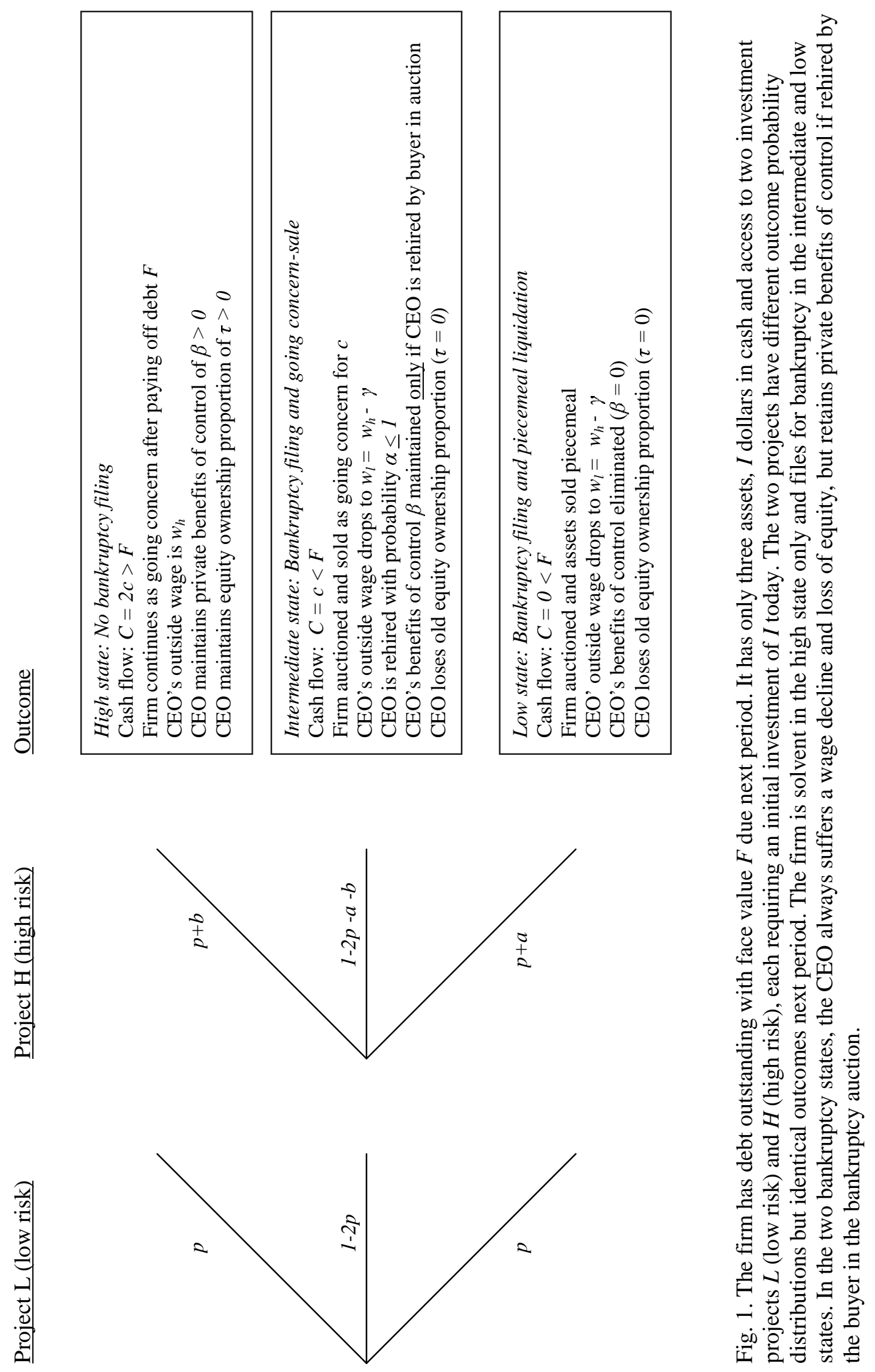


Number of bankruptcy auctions

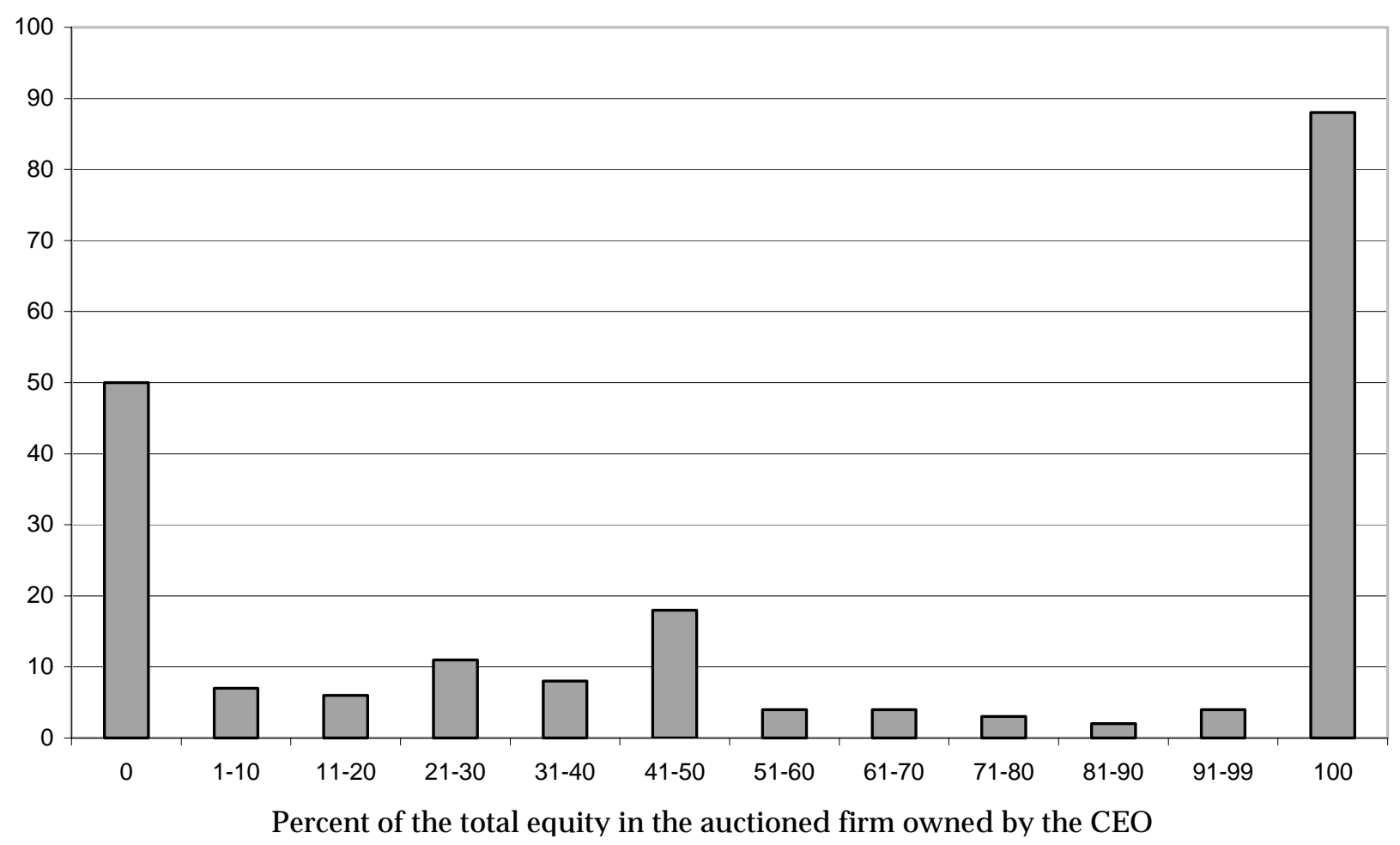

Fig. 2. Frequency distribution of the percentage chief executive officer (CEO) equity ownership in 205 privately held Swedish firms filing for bankruptcy, 1988-1991. 
Median CEO income index

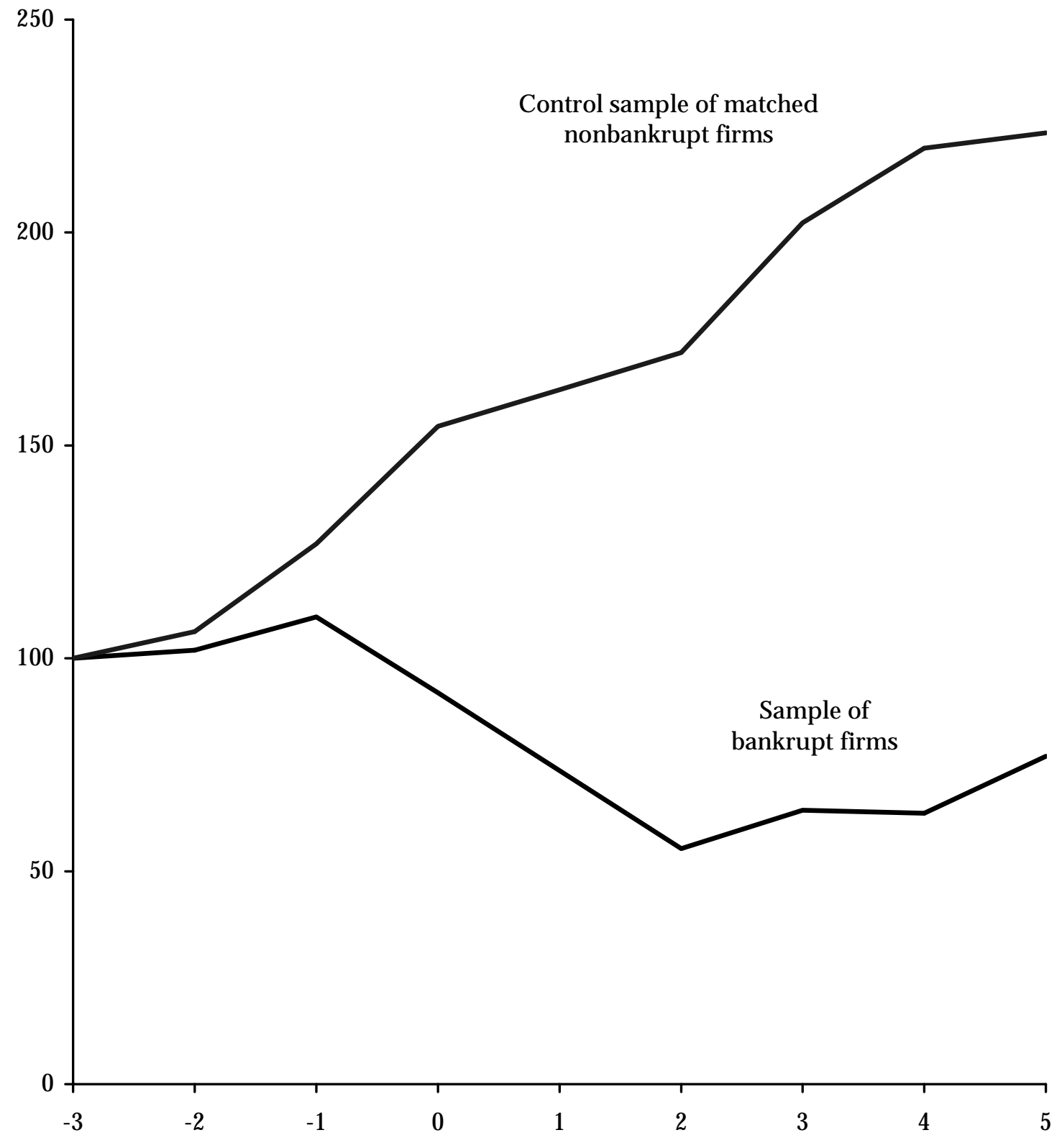

Year relative to the year of bankruptcy filing (year 0)

Fig. 3. Evolution of a median income index for chief executive officers (CEOs) of bankrupt and nonbankrupt firms. The figure plots the annual values of $\hat{c}_{t}=\hat{c}_{t-1} \Delta c_{t}^{m}$, where $\Delta c_{t}^{m}$ is the median rate of change in CEO taxable income $\Delta c_{t}=\left(c_{t}-c_{t-1}\right) / c_{t-1}$, and $\hat{c}_{-3} \equiv 100$. Year $t$ is the year relative to the year of bankruptcy filing (year 0 ). The lower index represents CEOs of firms filing for bankruptcy, while the upper index represents CEOs of non-bankrupt firms matched on fourdigit industry and asset size. The total sample is composed of 258 privately held Swedish firms filing for bankruptcy, 1988-1991. 